UNIVERSIDADE DE SÃO PAULO

FACULDADE DE ZOOTECNIA E ENGENHARIA DE ALIMENTOS

CAMILLA DE SOUZA

Avaliação do RNA mensageiro relacionado aos podócitos no sedimento urinário de cães saudáveis e com doença renal crônica

Pirassununga 
CAMILLA DE SOUZA

Avaliação do RNA mensageiro relacionado aos podócitos no sedimento urinário de cães saudáveis e com doença renal crônica

\section{Versão Corrigida}

Dissertação apresentada à Faculdade de Zootecnia e Engenharia de Alimentos da Universidade de São Paulo, como parte dos requisitos para a obtenção do Título de Mestre em Ciências.

Área de concentração: Biociência Animal

Orientadora: Profa. Dra. Deise Carla Almeida Leite Dellova 
Ficha catalográfica elaborada pelo Serviço de Biblioteca e Informação, FZEA/USP, com os dados fornecidos pelo(a) autor(a)

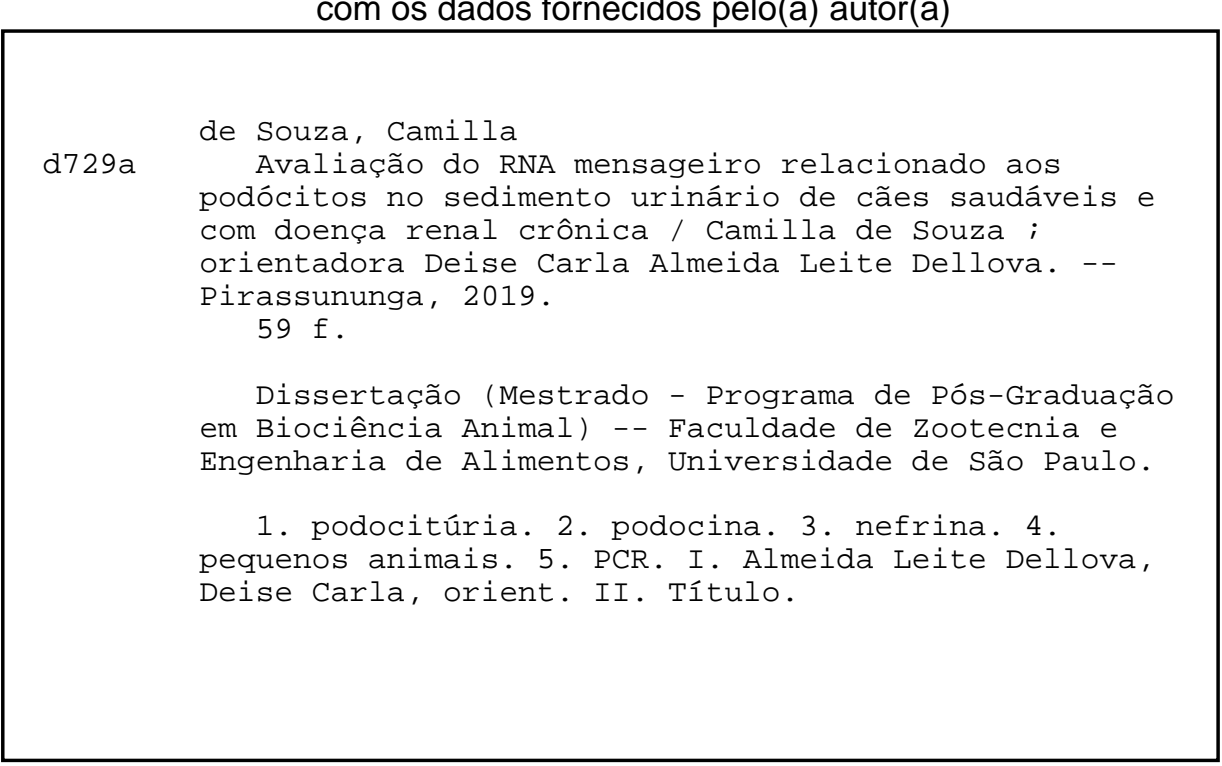

Permitida a cópia total ou parcial deste documento, desde que citada a fonte - o autor 


\title{
Avaliação do RNA mensageiro relacionado aos podócitos no sedimento urinário de cães saudáveis e com doença renal crônica
}

\author{
Dissertação apresentada à Faculdade de \\ Zootecnia e Engenharia de Alimentos da \\ Universidade de São Paulo, como parte dos \\ requisitos para a obtenção do Título de Mestre \\ em Ciências.
}

Área de concentração: Biociência Animal

\section{Data de aprovação: $25 / 06 / 2019$}

Prof. Dr. (a) André Luiz Baptista Galvão

Instituição: Universidade de Araraquara

Assinatura:

Prof. Dr. Juliano Coelho da Silveira

Instituição: Faculdade de Zootecnia e Engenharia de Alimentos - USP

Assinatura:

Prof. Dr.(a) Trícia Maria Ferreira de Sousa Oliveira

Instituição: Faculdade de Zootecnia e Engenharia de Alimentos - USP

Assinatura: 


\section{DEDICATÓRIA}

Essa e todas as minhas outras conquistas, e ainda aquelas que estão por vir, dedico aos meus pais,

Sheila de Souza e Végno de Souza.

Por sempre acreditarem em mim, por todos os ensinamentos,

pelo exemplo que são de respeito, honestidade e sabedoria. 


\section{AGRADECIMENTOS}

À Deus, por ter me concedido força e sabedoria nos momentos mais difíceis.

Aos meus pais, Sheila e Végno, por toda a motivação, palavras de amor e carinho, compreensão e apoio sempre. Ao meu parceiro de vida, Daniel, por toda a paciência, carinho e apoio.

À Faculdade de Zootecnia e Engenharia de Alimentos da Universidade de São Paulo e ao programa de Biociência Animal, pela oportunidade de realização do curso de mestrado.

À Coordenação de Aperfeiçoamento de Pessoal de Nível Superior (CAPES), pelos fomentos neste estudo.

A minha orientadora, Deise Carla Almeida Leite Dellova, pela paciência, apoio e confiança no meu trabalho, além de conselhos nas horas difíceis.

A todos os colegas de trabalho e funcionários que participaram deste estudo, principalmente,

o Prof. Dr. Heidge Fukumasu, a auxiliar de laboratório Arina Lazaro Rochetti e a médica veterinária Daniele Passarelli, por todo o apoio e dedicação.

A todos os animais que já passaram pela minha vida, em especial as minhas gatinhas mais lindas do mundo Mel, Marrie e Zara, por toda a troca de amor e carinho, e por sempre reforçar que eu não poderia ter escolhido qualquer outra profissão.

A todos os meus amigos, em especial Daisy, Cláudia, Luiza, Aska, Bruna pela cumplicidade de todos esses anos.

\section{Muito obrigada!}




\section{EPÍGRAFE}

"Sem sonhos, a vida não tem brilho. Sem metas, os sonhos não têm alicerces. Sem prioridades, os sonhos não se tornam reais. Sonhe, trace metas, estabeleça prioridades e corra riscos para executar seus sonhos. Melhor é errar por tentar do que errar por se omitir."

Augusto Cury 


\section{RESUMO}

DE SOUZA, C. Avaliação do RNA mensageiro relacionado aos podócitos no sedimento urinário de cães saudáveis e com doença renal crônica. 2019. 59 f. Dissertação (Mestrado em Biociência Animal) - Faculdade de Zootecnia e Engenharia de Alimentos, Universidade de São Paulo, Pirassununga, 2019.

A doença renal crônica (DRC) é frequentemente diagnosticada em cães de meia idade e idosos; possui caráter progressivo e pode ser o resultado da perda da integridade dos componentes da barreira de filtração glomerular (BFG), incluindo os podócitos. Portanto, o objetivo desta pesquisa foi avaliar a expressão do RNAm relacionado aos podócitos no sedimento urinário de cães hígidos ou com DRC, procurando-se estimar a podocitúria e a condição da BFG. Após a avaliação clínica e laboratorial, os cães normohidratados foram divididos em três grupos: controle $(\mathrm{n}=10), \mathrm{DRC}$ em estádios 1 e $2\left(\mathrm{DRC}_{1-2}\right)(\mathrm{n}=5)$ e $\mathrm{DRC}$ em estádios 3 e $4\left(\mathrm{DRC}_{3-4}\right)(\mathrm{n}=9)$, de acordo com o estabelecido pela International Renal Interest Society (IRIS). O RNAm foi determinado no sedimento urinário dos cães por PCR em tempo real. A porcentagem de detecção do RNAm para nefrina (NPHS1) e podocina (NPHS2) foi maior nas amostras de sedimento urinário de cães com $\mathrm{DRC}_{1-2}$ e menor em cães com $\mathrm{DRC}_{3-4}$, quando comparados aos cães controle $(\mathrm{P}<0,001)$. $\mathrm{O}$ grupo $\mathrm{DRC}_{3-4}$ apresentou menor expressão relativa média do $N P H S 2$ no sedimento urinário, em relação ao grupo $\mathrm{DRC}_{1-}$ ${ }_{2}(\mathrm{P}<0,05)$, mas não diferiu do controle $(\mathrm{P}=0,082)$. Os resultados demonstraram que os cães podem apresentar podocitúria fisiológica e relacionado à DRC. Além disso, a podocitúria variou de acordo com os estádios da DRC, estando aumentada nos cães em estádio 1 e 2 e diminuída nos cães em estádio 3 e 4. Portanto, a excreção urinária do NPHS1 e NPHS2 mostrou-se um parâmetro muito promissor para o acompanhamento de cães com DRC.

Palavras-chave: nefrina, PCR, pequenos animais, podocina, podocitúria. 


\begin{abstract}
DE SOUZA, C. Evaluation of messenger RNA related to podocytes in the urinary sediment of healthy and chronic kidney disease dogs. 2019. 59 f. M.Sc. Dissertation Faculdade de Zootecnia e Engenharia de Alimentos, Universidade de São Paulo, Pirassununga, 2019.

Chronic kidney disease (CKD) is often diagnosed in middle-aged and elderly dogs; is a progressive disease and may be the result of loss of integrity of glomerular filtration barrier (GFB) components, including podocytes. Therefore, the objective of this research was to evaluate the expression of mRNA related to podocytes in the urinary sediment of healthy or CKD dogs, aiming to estimate the podocyturia and GFB condition. After clinical and laboratory evaluation the normohydrated dogs were divided into three groups: control $(\mathrm{n}=$ 10), stage 1 and 2 CKD $\left(\mathrm{DRC}_{1-2}\right)(\mathrm{n}=5)$ and stage 3 and $4 \mathrm{CKD}\left(\mathrm{DRC}_{3-4}\right)(\mathrm{n}=9)$, according to International Renal Interest Society (IRIS). The mRNA was determined in the urinary sediment of dogs by real-time PCR. The percentage of nephrine (NPHS1) and podocin (NPHS2) mRNA detection was higher in urine sediment samples from dogs with $\mathrm{DRC}_{1-2}$ and lower in dogs with $\mathrm{DRC}_{3-4}$ when compared to control dogs $(\mathrm{P}<0.001)$. The $\mathrm{DRC}_{3-4}$ group presented lower mean relative expression of $N P H S 2$ in urine sediment in relation to the $\mathrm{DRC}_{1 \text { - }}$ 2 group $(\mathrm{P}<0.05)$ but did not differ from the control $(\mathrm{P}=0.082)$. The results showed that dogs can present physiological and CKD related podocyturia. In addition, podocyturia varied according to CKD stages, that is, it has been increased in dogs in stage 1 and 2 and decreased in dogs in stage 3 and 4. Therefore, the urinary excretion of NPHS1 and NPHS 2 showed to be a very promising for evaluation of dogs with CKD.
\end{abstract}

Keywords: nephrin, PCR, podocin, podocyturia, small animals. 


\section{LISTA DE ILUSTRAÇÕES}

Figura 1 - Corte longitudinal do rim unilobado de um cão ............................................... 15

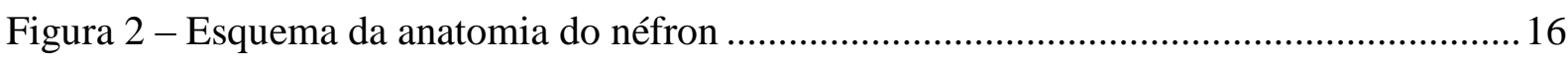

Figura 3 - Corpúsculo renal e aparelho justaglomerular..................................................... 16

Figura 4 - Estrutura da barreira de filtração glomerular (BFG) ............................................ 17

Figura 5 - Mensuração da pressão arterial sistólica em um cão do estudo ............................... 32

Figura 6 - Organograma para avaliação dos cães e realização das análises ............................36

Figura 7 - Valores médios de pressão arterial sistólica (PAS) nos grupos experimentais....... 39

Figura 8 - Valores médios de relação proteína/creatinina urinária (PU/C) nos grupos

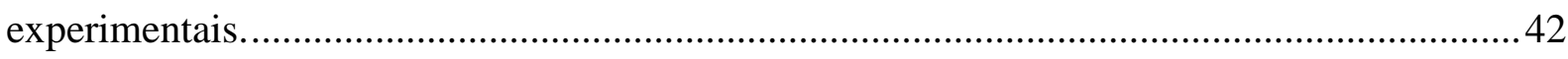

Figura 9 - Imagens ultrassonográficas dos rins de cão. ................................................... 42

Figura 10 - Eletroforese do RNA total extraído do sedimento urinário de cães...................... 44

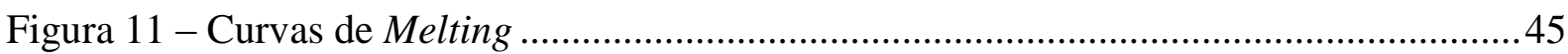




\section{LISTA DE QUADROS}

Quadro 1 - Estadiamento da doença renal crônica...............................................................2 23

Quadro 2 - Subestadiamento da doença renal crônica ........................................................ 24

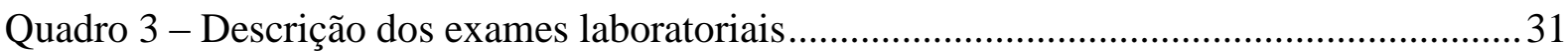




\section{LISTA DE TABELAS}

Tabela 1 - Primers utilizados na realização do PCR em tempo real........................................ 35

Tabela 2 - Raça, idade e sexo dos cães selecionados para o projeto ......................................... 37

Tabela 3 - Valores médios do peso corporal, ECC e EMM dos grupos experimentais............38

Tabela 4 - Valores médios do eritrograma, contagem de plaquetas e de leucócitos dos grupos

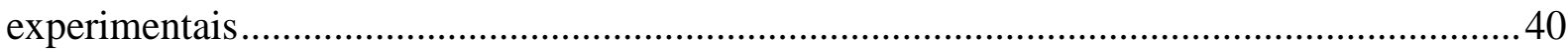

Tabela 5 - Valores médios do perfil bioquímico e eletrolítico dos grupos experimentais ...... 41

Tabela 6 - Valores médios da densidade e $\mathrm{pH}$ urinários dos grupos experimentais................41

Tabela 7 - Estadiamento da doença renal crônica (DRC) dos cães incluídos neste estudo. .... 43

Tabela 8 - Valores individuais e médios da concentração do RNA urinário e sua respectiva razão de pureza dos cães do grupo controle e DRC

Tabela 9 - Porcentagem de detecção do NPHS1 nas amostras do sedimento urinário dos cães dos grupos controle e $\mathrm{DRC}_{1-2}$

Tabela 10 - Porcentagem de detecção do NPHS1 nas amostras do sedimento urinário dos cães dos grupos controle e $\mathrm{DRC}_{3-4}$

Tabela 11 - Porcentagem de detecção do NPHS2 nas amostras do sedimento urinário dos cães dos grupos controle e $\mathrm{DRC}_{1-2}$

Tabela 12 - Porcentagem de detecção do NPHS2 nas amostras do sedimento urinário dos cães dos grupos controle e $\mathrm{DRC}_{3-4}$

Tabela 13 - Valores médios da expressão relativa do NPHS1 e NPHS2 no sedimento urinário dos grupos experimentais

Tabela 14 - Correlações avaliadas 


\section{LISTA DE ABREVIAÇÕES E SIGLAS}

$\begin{array}{ll}\text { AAF } & \text { Arteríola aferente } \\ \text { AEF } & \text { Arteríola eferente } \\ \text { BFG } & \text { Barreira de filtração glomerular } \\ \text { CPT } & \text { Capilar peritubular } \\ \text { DRC } & \text { Doença renal crônica }\end{array}$

ECA Enzima conversora da angiotensina

ECC Escore de condição corporal

EMM Escore de massa muscular

HAD Hormônio antidiurético

IRIS International Renal Interest Society

NPHS1 Gene nefrina

NPHS2 Gene podocina

NPHS1 RNAm nefrina

NPHS2 RNAm podocina

PAS Pressão arterial sistólica

PCR Polymerase Chain Reaction

PU/C Relação proteína/creatinina urinária

ERA Ramo ascendente espesso

RAF Ramo ascendente fino

RDF Ramo descendente fino

RNAm Ácido ribonucleico mensageiro

SDMA Dimetil arginina simétrica

SRAA Sistema renina angiotensina aldosterona

TCD Túbulo contorcido distal

TCP Túbulo contorcido proximal

TFG Taxa de filtração glomerular

UDCH Unidade Didático Clínico Hospitalar 


\section{SUMÁRIO}

1 INTRODUÇÃ

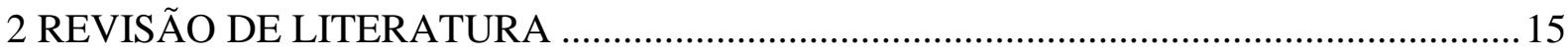

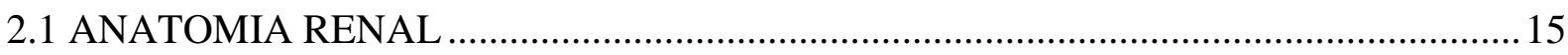

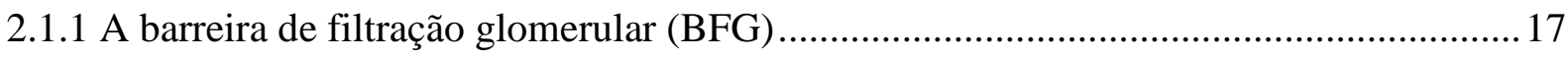

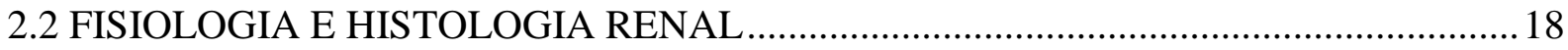

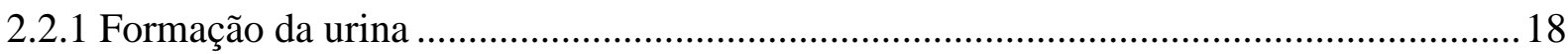

2.2.2 Taxa de filtração glomerular (TFG) ….................................................................. 19

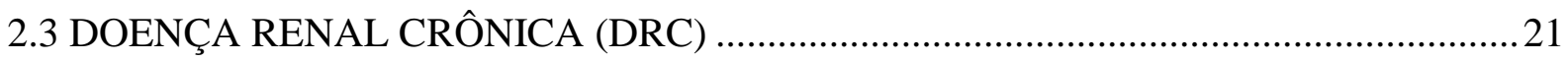

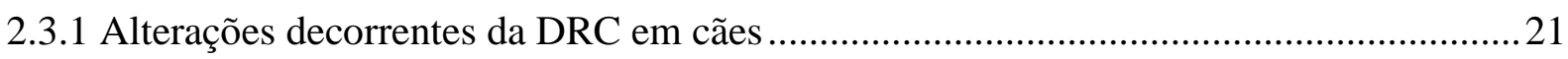

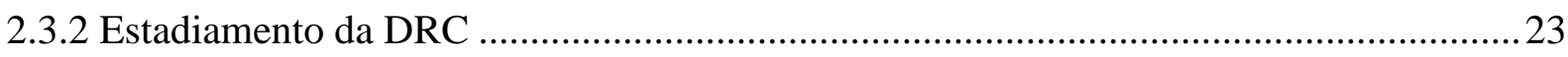

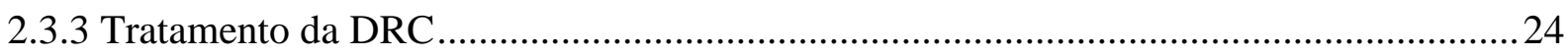

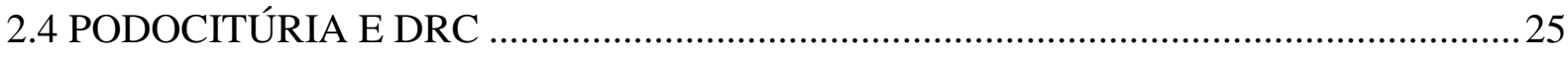

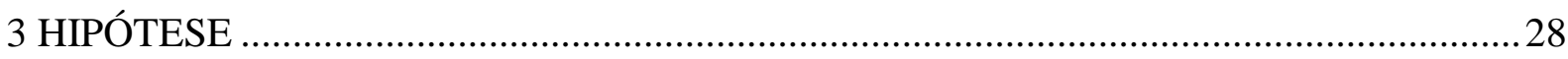

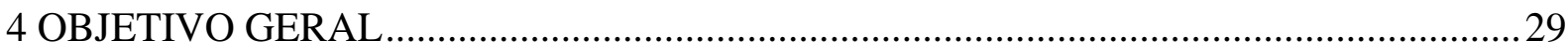

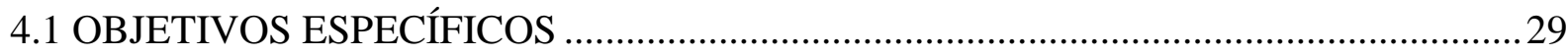

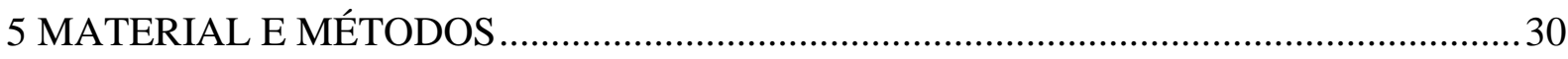

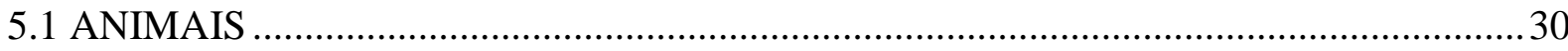

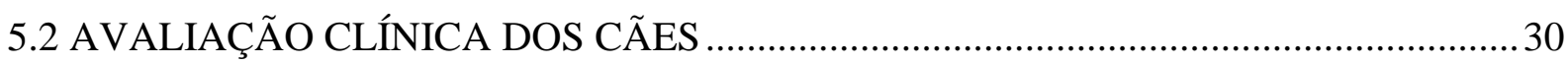

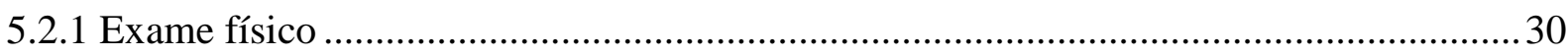

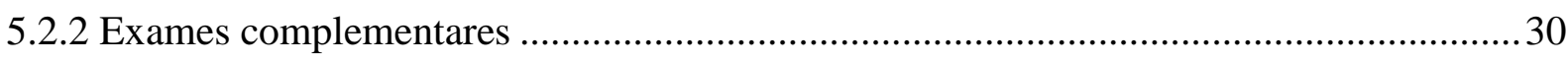

5.2.3 Mensuração da pressão arterial (PA) não invasiva................................................. 31

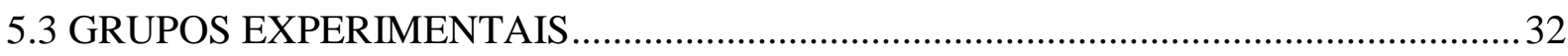

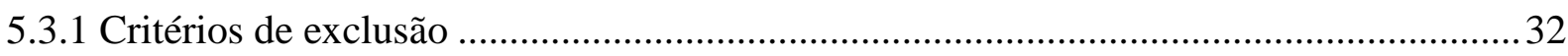

5.4 EXTRAÇÃO DO RNA DO SEDIMENTO URINÁRIO DOS CÃES ..............................33

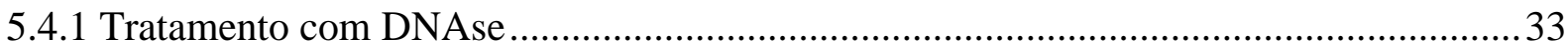

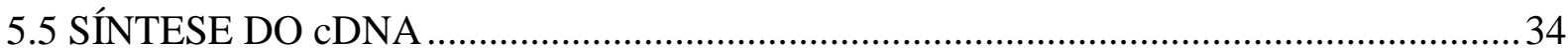


5.6 AVALIAÇÃO E QUANTIFICAÇÃO DA EXPRESSÃO DO NPHS1 E NPHS2 POR

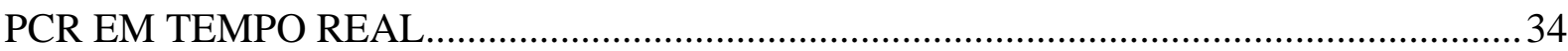

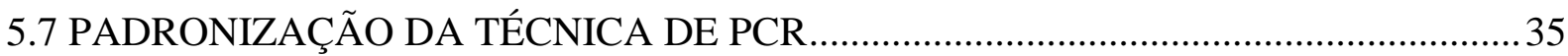

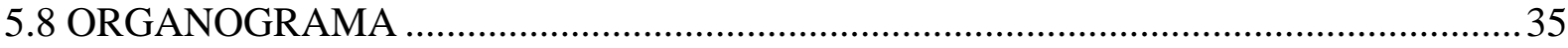

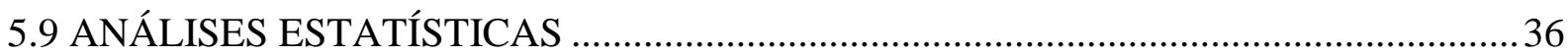

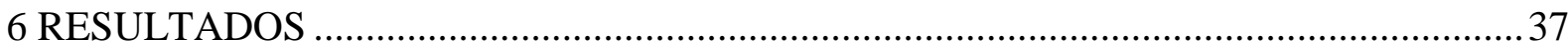

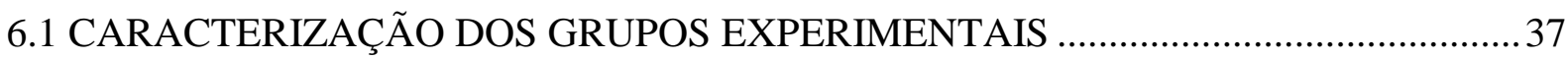

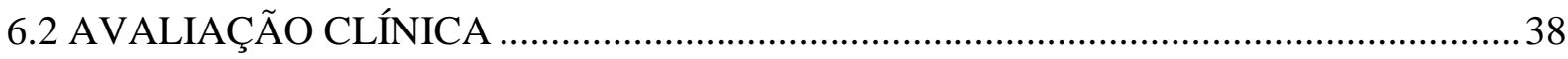

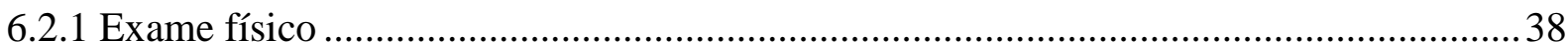

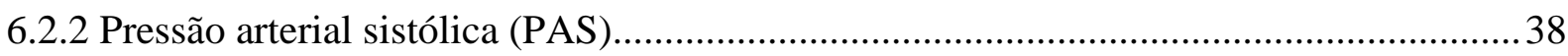

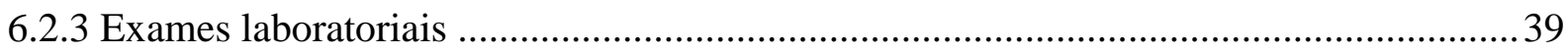

6.2.3.1 Eritograma, contagem de plaquetas e leucócitos ......................................................... 39

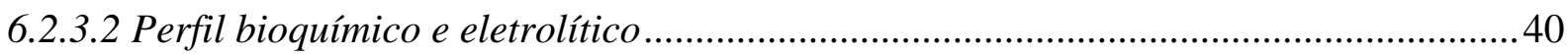

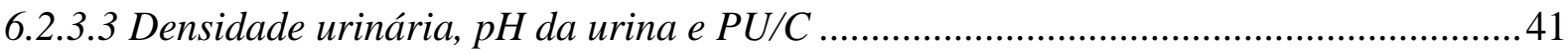

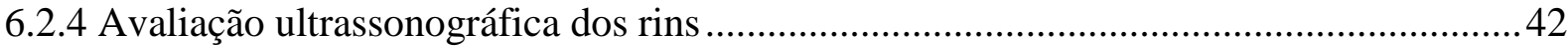

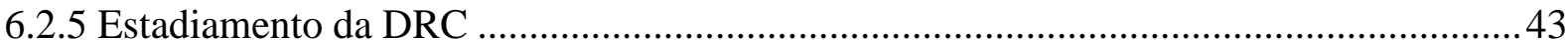

6.3 AVALIAÇÃO DO RNA EXTRAIIDO DO SEDIMENTO URINÁRIO DOS CÃES .......43

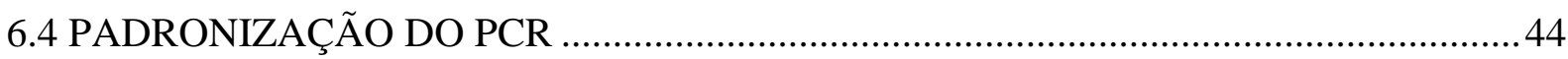

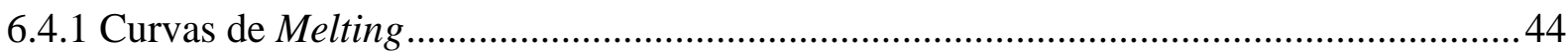

6.4.2 Detecção do NPHS1 e NPHS2 e 18S no sedimento urinário dos cães ............................46

6.4.3 Comparação entre os grupos em relação à expressão relativa do NPHS1 e NPHS2 no

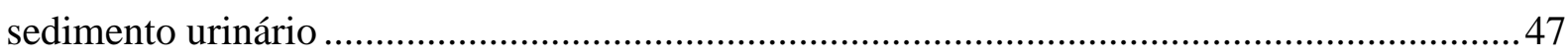

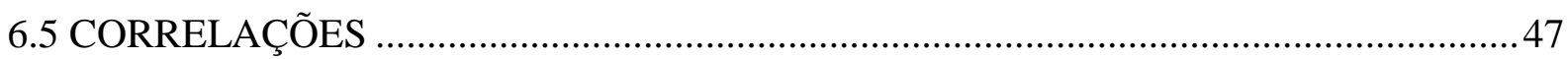

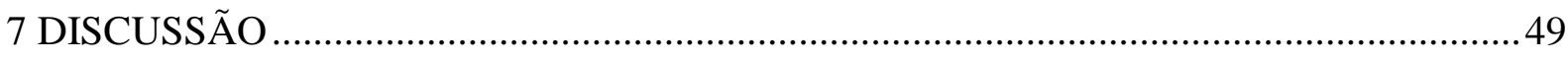

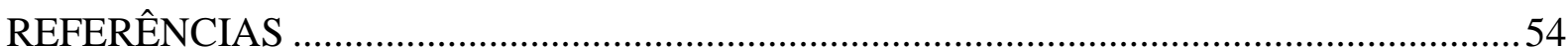




\section{INTRODUÇÃO}

A doença renal crônica (DRC) é uma das principais causas de morbidade e mortalidade em cães idosos (NABITY et al., 2011). É caracterizada por lesões irreversíveis no parênquima renal, que comprometem a estrutura e a função dos néfrons (WAKI et al., 2010). De acordo com Mallipattu e He (2016), a DRC é uma consequência direta da disfunção e lesão da barreira de filtração glomerular (BFG).

Na prática clínica, o diagnóstico da DRC em cães é realizado, principalmente, pelos testes que estimam a filtração glomerular, dos quais o mais utilizado é a mensuração da concentração sérica de creatinina, além da urinálise e das técnicas de diagnóstico por imagem (RUFATO et al., 2011). Recentemente, a dimetil arginina simétrica (SDMA), outro marcador relacionado à filtração glomerular, tem sido utilizado (YERRAMILLI et al., 2016). Porém estes testes e técnicas não são específicos para a avaliação da integridade da BFG em condições normais ou na DRC.

Os podócitos são elementos celulares fundamentais para a manutenção da BFG, porque revestem a membrana basal glomerular e os seus prolongamentos, os processos podais, formam os poros de filtração, que são responsáveis pela retenção das macromoléculas durante a depuração plasmática (DOUBLIER et al., 2001). Apesar disso, os podócitos podem se desprender da membrana basal, sendo eliminados pela urina e dando origem à podocitúria.

As doenças renais podem aumentar a podocitúria e até ocasionar a depleção dos podócitos, tendo como consequência o aumento da proteinúria (SABINO et al., 2013).

Estudos demonstraram que a avaliação do RNA mensageiro (RNAm) associado aos podócitos, em amostras de urina de seres humanos, auxilia na avaliação da integridade da BFG e progressão das doenças renais, em complemento à análise da proteinúria, e de uma forma menos invasiva do que a biópsia renal (YU, et al., 2005; TIMM et al., 2016). Entretanto, informações semelhantes são bem mais escassas na clínica veterinária, apesar dos vários casos de DRC na rotina de atendimento de cães.

Sendo assim, é possível que a determinação da expressão do RNAm relacionado aos podócitos na urina de cães saudáveis e com DRC possibilite a caracterização e diferenciação da podocitúria fisiológica e relacionada à doença, em associação com a condição da BFG. 


\section{REVISÃO DE LITERATURA}

\subsection{ANATOMIA RENAL}

Os rins se localizam na região sublombar, paralelos à coluna vertebral. São órgãos pares, retroperitoneais, revestidos por uma cápsula fibrosa e que apresentam uma borda côncava e outra convexa. Na borda côncava encontra-se o hilo, que contém os vasos sanguíneos e nervos. O parênquima renal é formado por duas regiões: cortical, mais externa e justamedular e medular, dividida em externa e interna (Figura 1) (AIRES, 2012).

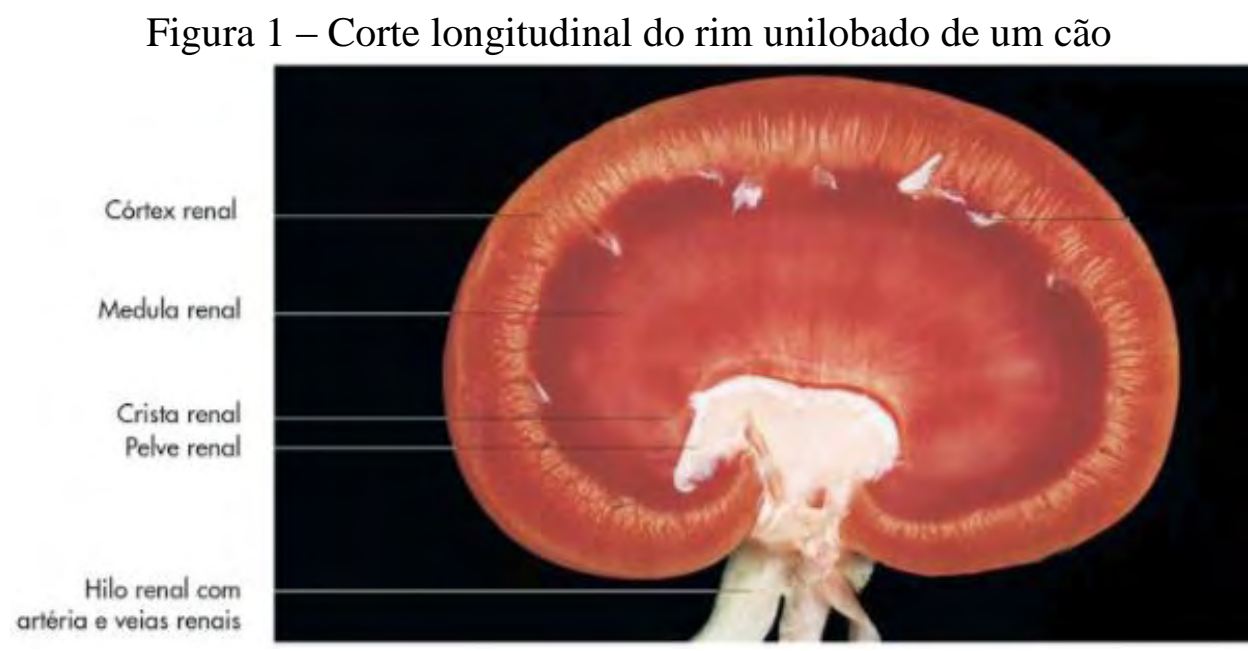

Fonte: König, Maierl e Liebich (2016).

Nos cães, o rim é unilobado e contém cerca de 400 mil néfrons (KÖNIG; MAIERL; LIEBICH, 2016). Cada néfron é formado pelo corpúsculo renal e uma estrutura tubular (Figura 2). O corpúsculo renal é constituído pelo glomérulo, que, por sua vez, é envolto pela cápsula de Bowman (Figura 3) (JUNQUEIRA; CARNEIRO, 2012). O glomérulo corresponde a um enovelado capilar, formado a partir da arteríola aferente. Esta se divide em alças capilares que são sustentadas por células mesangiais e depois se fundem para formar a arteríola eferente (AIRES, 2012). A estrutura tubular compreende o túbulo proximal, a alça de Henle e o túbulo contorcido distal, que, por sua vez, drena para o ducto coletor. $\mathrm{O}$ rim do cão possui apenas uma papila renal, onde se encontram os ductos papilares, formados a partir da junção dos ductos coletores. Os ductos papilares desembocam na crista renal (Figura 1). A pelve renal é moldada ao redor da crista renal e se prolonga ventralmente até o ureter (KÖNIG; MAIERL; LIEBICH, 2016). 
Figura 2 - Esquema da anatomia do néfron

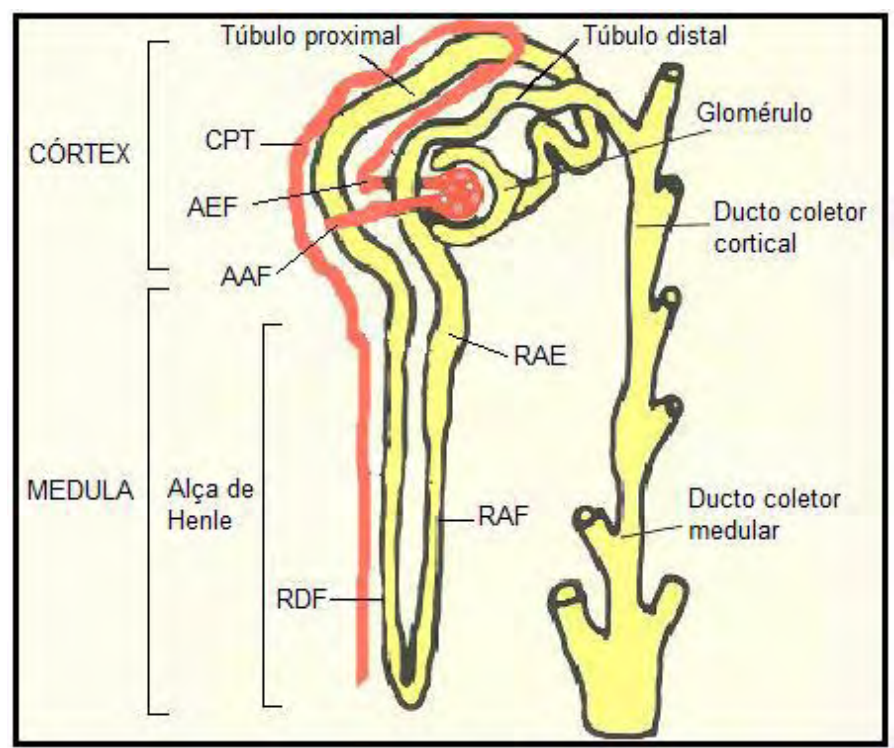

AAF- arteríola aferente, AEF- arteríola eferente, CPT- capilar peritubular, RDF- ramo descendente fino, RAF- ramo ascendente fino, RAE- ramo ascendente espesso. Fonte: Geist e Langston (2011).

Figura 3 - Corpúsculo renal e aparelho justaglomerular

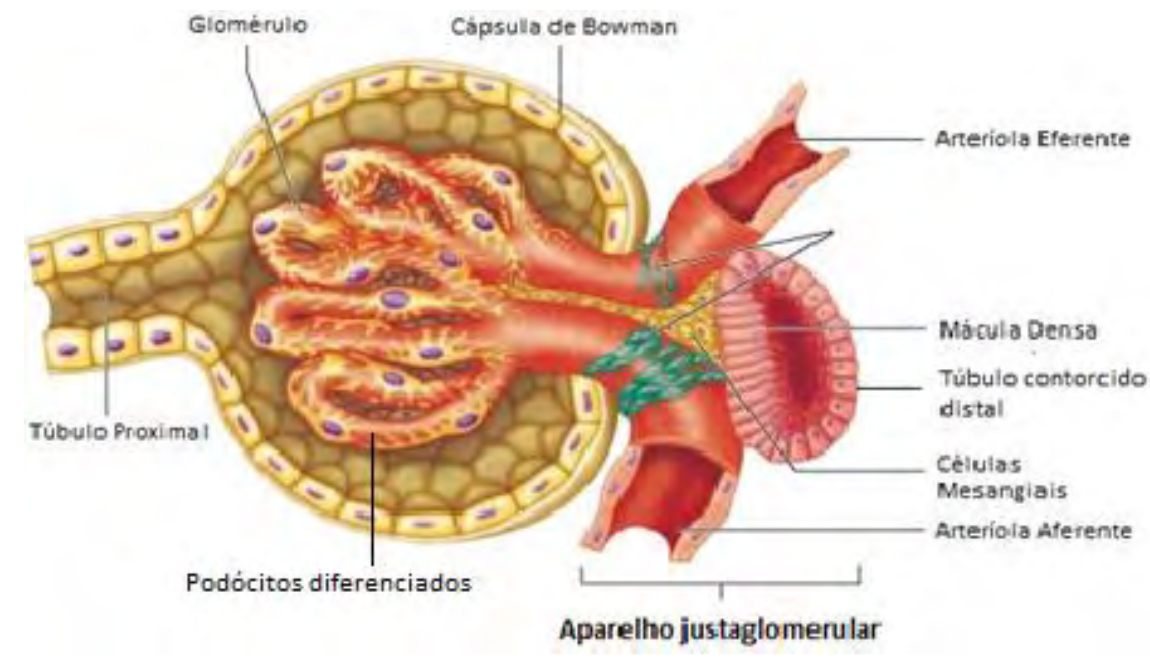

Na imagem é possível observar os podócitos diferenciados recobrindo os capilares glomerulares. Fonte: Geist e Langston (2011).

No ponto de contato entre o túbulo contorcido distal e o glomérulo, as células da camada média da arteríola aferente se diferenciam nas células granulares, produtoras de renina, e as células tubulares dão origem à mácula densa, que detecta variações no volume e composição do fluido tubular. O conjunto destas estruturas é denominado aparelho justaglomerular (Figura 3), que tem papel importante na ativação do sistema reninaangiotensina-aldosterona (SRAA) (AIRES, 2012; JUNQUEIRA; CARNEIRO, 2012). 
2.1.1 A barreira de filtração glomerular (BFG)

A BFG é composta por células endoteliais dos capilares glomerulares, pela membrana basal glomerular e pelos podócitos (Figura 4A). Os podócitos são células epiteliais diferenciadas que revestem a membrana basal, sendo que os seus prolongamentos, denominados de processos podais, formam os poros de filtração da BFG. Esses poros, por sua vez, são recobertos por uma membrana, denominada diafragma, que une os processos podais adjacentes e promove a retenção de macromoléculas circulantes, à medida que o plasma é filtrado no glomérulo (DOUBLIER et al., 2001).

Figura 4 - Estrutura da barreira de filtração glomerular (BFG)

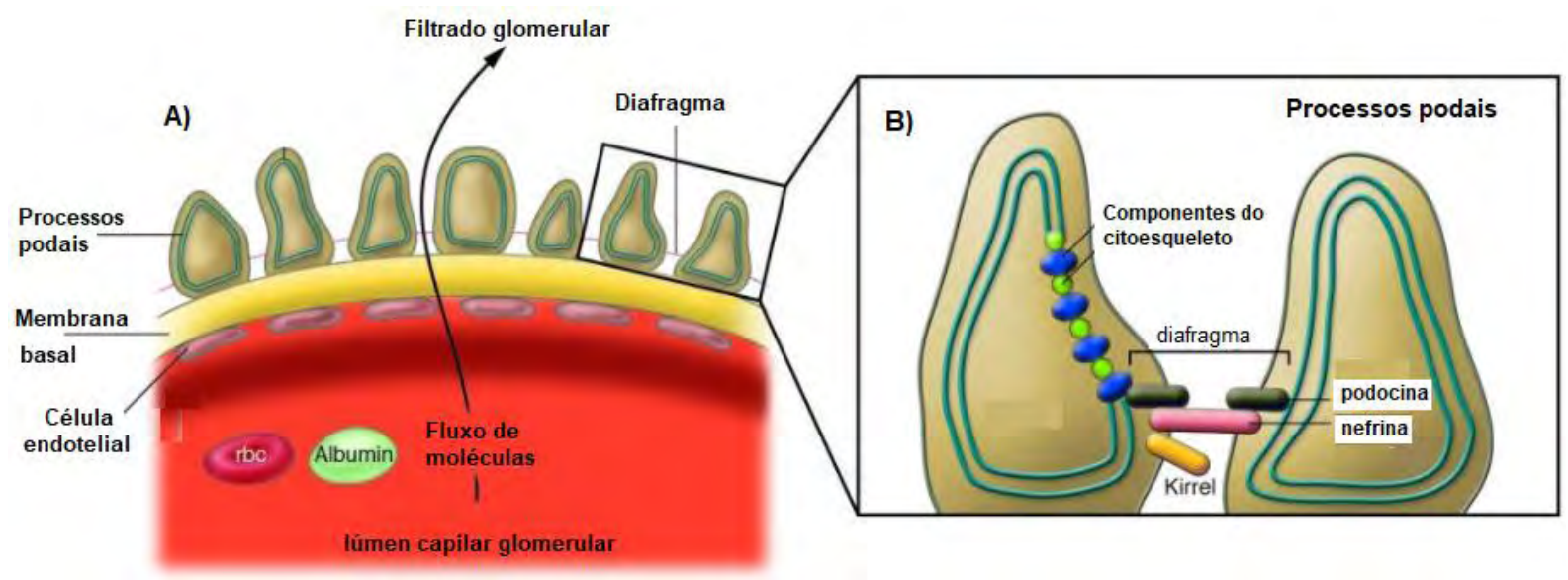

A) Componentes da BFG: células endoteliais, membrana basal e podócitos diferenciados apresentando os processos podais. B) Os processos podais adjacentes são conectados pela membrana diafragma. A nefrina é a proteína central do diafragma e contribui para a estrutura e manutenção da fenda de filtração, como uma barreira física às proteínas plasmáticas. A podocina está envolvida na ligação da nefrina ao citoesqueleto de actina, fornecendo integridade estrutural aos processos podais. O plasma que entra nos capilares glomerulares é filtrado através do endotélio, membrana basal e os poros para produzir o filtrado glomerular. Em condições normais, as macromoléculas, como a albumina, não atravessam os poros de filtração. Fonte: Adaptado de Quaggin (2009).

O diafragma é constituído por diversas proteínas, entre elas a nefrina e a podocina (Figura 4B) (ICHII et al., 2011). A nefrina é uma glicoproteína transmembrana que pertence à superfamília das imunoglobulinas, envolvidas com a adesão célula a célula e é codificada pelo gene NPHS1 (484571 nefrina) (INOUE; ISHIBE, 2015). A podocina é uma proteína da família da estomatina, envolvida com a ligação entre a nefrina e o citoesqueleto de actina do podócito, sendo codificada pelo gene NPHS2 (490323 podocina). A interação nefrinapodocina é muito importante para a manutenção da arquitetura do diafragma e a manutenção da seletividade da BFG (GÖDEL et al., 2013). 


\subsection{FISIOLOGIA E HISTOLOGIA RENAL}

Os rins possuem como função primária, a produção de urina. No decorrer deste processo, promovem homeostase, por meio da preservação de água e solutos, como glicose e aminoácidos; manutenção do equilíbrio ácido-base, uma vez que regulam as concentrações de íons hidrogênio e bicarbonato; e excreção de resíduos, a exemplo dos compostos nitrogenados. Os rins também apresentam função endócrina, representada pela produção de vitamina $\mathrm{D}$ ativa e eritropoietina (que estimula a hematopoiese) e aumento das concentrações circulantes de angiotensina e aldosterona, pela ação da renina (JUNQUEIRA; CARNEIRO, 2012).

\subsubsection{Formação da urina}

Cerca de $20 \%$ do débito cardíaco são direcionados aos rins, por meio das artérias renais, que se originam da aorta abdominal. No parênquima renal, as artérias renais se ramificam nas artérias interlobares, estas em artérias arqueadas, que, posteriormente, darão origem às artérias interlobulares. As arteríolas aferentes partem das artérias interlobulares para entrarem no corpúsculo renal e formarem as alças capilares do glomérulo (KÖNIG; MAIERL; LIEBICH, 2016). Como citado anteriormente, as células endoteliais dos capilares glomerulares, em conjunto com a membrana basal e os podócitos, formam a BFG, que permite a passagem de água e elementos acelulares do sangue para o espaço de Bowman e, assim, ocorre a formação do ultrafiltrado (KIERSZENBAUM, 2008).

Inicialmente, o ultrafiltrado possui uma composição eletrolítica semelhante à do plasma. À medida que passa pelos túbulos renais, sua composição é modificada, em consequência do mecanismo de reabsorção e secreção das células tubulares (KIERSZENBAUM, 2008).

A reabsorção e a secreção de substâncias variam entre os segmentos tubulares. No túbulo contorcido proximal (TCP), ocorre cerca de $70 \%$ de reabsorção de cloreto de sódio filtrado. Além disso, quantidades variáveis de potássio, fosfato, bicarbonato, cálcio, ureia, magnésio e ácido úrico também são reabsorvidas no TCP. Neste segmento há secreção de hidrogênio e íons orgânicos, além de amônia e creatinina (SOUZA; ELIAS, 2006; AIRES, 2012).

A continuidade do TCP é denominada de alça de Henle, com um ramo descendente e outro ascendente. Estes dois ramos apresentam alta permeabilidade a sais e ureia; entretanto, 
somente o ramo descendente é permeável à água. No ramo ascendente, a grande reabsorção de solutos e a impermeabilidade à água são responsáveis pela manutenção da hipertonicidade do interstício na região medular, condição que permite a reabsorção de água no ducto coletor e a formação de uma urina concentrada (GOBE; JOHNSON, 2007; AIRES, 2012).

Tanto o ramo ascendente alça de Henle, quanto o túbulo contornado distal (TCD), possuem grande capacidade de transporte ativo de solutos, como sódio, cloreto, cálcio e magnésio, o que também contribui para a formação de um interstício medular mais concentrado do que o fluido tubular (GOBE; JOHNSON, 2007).

O sistema de ductos coletores se inicia na região de transição do TCD para o túbulo coletor inicial. Os túbulos coletores iniciais desembocam no ducto coletor, descem pelo córtex e pela medula até a extremidade papilar, onde o líquido tubular é lançado na pelve renal (SOUZA; ELIAS, 2006).

As células do TCD e ducto coletor controlam a fase final de excreção de eletrólitos e água. Estas porções tubulares apresentam alta densidade de receptores para aldosterona, peptídeo natriurético atrial e hormônio antidiurético (HAD ou vasopressina). A aldosterona, um hormônio esteroide produzido nas glândulas adrenais, estimula a reabsorção de sódio e a secreção de hidrogênio e potássio, interferindo, portanto, na retenção de água e no pH urinário. Além disso, a aldosterona é principal determinante da concentração de potássio no fluido extracelular. O peptídeo natriurético atrial, produzido por células atriais cardíacas, é promotor da secreção de sódio e da eliminação de uma urina mais diluída. O HAD, produzido no hipotálamo e armazenado na hipófise, determina a concentração final da urina excretada, por meio da inserção de canais de água (aquaporinas) na membrana luminal dos ductos coletores. A inserção das aquaporinas é dependente do volume corporal do animal, ou seja, em situações de sobrecarga hídrica, a secreção do HAD está inibida, o que torna o ducto coletor relativamente impermeável à água e resulta na eliminação de uma urina diluída; porém, na hipovolemia, a secreção do HAD é estimulada, fazendo com que o ducto coletor se torne altamente permeável à água, resultando em uma urina concentrada (AIRES, 2012).

\subsubsection{Taxa de filtração glomerular (TFG)}

A BFG é permeável, mas impede que as células sanguíneas e as macromoléculas plasmáticas sejam filtradas; entretanto, alterações na permeabilidade dos capilares glomerulares e nas pressões oncótica do plasma, hidráulica nos capilares glomerulares e hidrostática na cápsula de Bowman podem modificar a TFG. A pressão hidráulica nos 
capilares glomerulares é definida pela resistência nas arteríolas aferente e eferente. $\mathrm{O}$ aumento da resistência na arteríola aferente, diminuiu a pressão hidráulica nos capilares e, consequentemente, a TFG; enquanto a diminuição da resistência nesta arteríola resultará no aumento da TFG. Já o aumento da resistência na arteríola eferente, aumenta a pressão hidráulica nos capilares e a TFG e a diminuição da resistência nesta arteríola também diminui a TFG. O aumento na pressão hidráulica nos capilares glomerulares ocasiona a dilatação dos poros da BFG, o que justifica, em parte, o aumento da TFG. $O$ aumento da resistência arteriolar é determinado por substâncias vasoconstritoras, como a noradrenalina e a angiotensina II; por outro lado, vasodilatadores, como o óxido nítrico e prostaglandinas reduzem a resistência arteriolar (AIRES, 2012).

O controle intrínseco da TFG é realizado pelo reflexo miogênico e a retroalimentação túbulo-glomerular. O reflexo miogênico ocorre como uma resposta da arteríola aferente às alterações na tensão da parede arteriolar, resultando em sua constrição imediata, após o aumento na tensão, e dilatação imediata, após diminuição da tensão. Este reflexo auxilia na manutenção da TFG e do fluxo sanguíneo renal, mesmo diante de modificações na pressão arterial sistêmica (PAS) (ROSS, 2012).

O mecanismo de retroalimentação túbulo-glomerular é controlado pelo aparelho justaglomerular; onde, o aumento do fluxo urinário na região da mácula densa leva ao aumento da resistência na arteríola aferente, reduzindo a TFG e o fluxo urinário, por um mecanismo não totalmente esclarecido (FUJII et al., 2013).

O SRAA é o principal fator humoral, responsável por regular a PAS e o volume sanguíneo renal (SOUZA; ELIAS, 2006). A renina, sintetizada no aparelho justaglomerular, catalisa a transformação de angiotensinogênio, produzido pelo fígado, em angiotensina I e esta, por sua vez, é convertida em angiotensina II pela enzima conversora da angiotensina (ECA) (SCHMIEDT et al., 2012). A angiotensina II possui ação vasoconstritora, que age para elevar a PAS e a pressão de perfusão renal. Além disso, é capaz de estimular a liberação de aldosterona pela glândula adrenal e de HAD pela hipófise. Estes hormônios estimulam a reabsorção de solutos e água, resultando no aumento do volume corporal e, consequentemente, da perfusão renal e da TFG (SCHMIEDT et al., 2012). 


\subsection{DOENÇA RENAL CRÔNICA (DRC)}

A DRC é caracterizada por lesões irreversíveis no parênquima renal, que comprometem a estrutura e função dos néfrons (BARTGES et al., 2012). É uma doença progressiva, frequentemente diagnosticada em animais idosos. Em um estudo realizado na Inglaterra com uma população geral de cães, foi observada uma prevalência que variou entre 0,05\% e 3,74\% (O'NEILL et al., 2013).

Possui caráter grave, uma vez que a disfunção glomerular e tubular afeta a excreção de substâncias tóxicas, o balanço hidroeletrolítico e a regulação da PAS (POLZIN, 2011); além disso, os animais em crise urêmica, eventualmente, podem vir à óbito (HALL et al., 2018).

A etiologia da DRC pode ser decorrente de fatores hereditários, congênitos ou adquiridos; contudo, os distúrbios glomerulares primários são propostos como as principais causas de DRC em cães (BORIN; CRIVELENTI; DE BRUM, 2009). Entretanto, a amiloidose, pielonefrite, urolitíase, displasia renal, nefrotoxinas, doença renal policística, doenças imunomediadas e infeciosas, como a leptospirose, a erliquiose e a leishmaniose, também podem ocasionar a DRC. Contudo, na maioria dos casos, o curso progressivo da DRC dificilmente permite estabelecer o insulto inicial desencadeante (NOTOMI et al., 2006).

\subsubsection{Alterações decorrentes da DRC em cães}

As manifestações clínicas da DRC em cães podem variar conforme a gravidade, duração e progressão da doença, além do tempo para o estabelecimento do diagnóstico (POLZIN; OSBORNE; ROSS, 2005). Entretanto, a poliúria e a polidipsia são os sinais precoces mais comumente observados em cães doentes renais crônicos. Já a oligúria pode ocorrer em pacientes desidratados ou na fase terminal da doença (NICHOLS, 2001).

Inicialmente, em resposta à lesão glomerular e redução da TFG, os cães apresentam o acúmulo de compostos nitrogenados na circulação (azotemia). A azotemia, por sua vez, resultará em uma intoxicação endógena gradual, comprometimento de várias funções do organismo e manifestações clínicas (uremia) (VANHOLDER et al., 2008).

As alterações digestórias são variáveis, como: hiporexia, anorexia e vômito, geralmente, decorrentes das alterações gastrointestinais provocados pela uremia; perda de peso, em consequência do aumento do catabolismo ou pela ingestão inadequada de calorias; halitose, devido ao acúmulo de amônia, uma vez que a redução da TFG leva à retenção de ureia, esta sofre degradação bacteriana no intestino, sendo convertida em amônia. A diarreia é 
observada com menos frequência em cães urêmicos. A hematoquesia, melena ou hematêmese pode ocorrer devida à redução da excreção renal de gastrina, resultando em ulcerações e/ou lesões nas mucosas gástrica e intestinal (VANHOLDER et al., 2008). Além disso, é comum a presença de sangramento gastrointestinal oculto que pode ser avaliada através de testes de sangue oculto nas fezes (CRIVELLENTI et al., 2017). O conjunto destas manifestações clínicas frequentemente resulta em desidratação, o que prejudica ainda mais a perfusão renal (NELSON; COUTO, 2015).

No sistema cardiovascular, a HAS é uma complicação comum, sendo que pode ocorrer em até 93\% dos cães doentes renais crônicos, em consequência à ativação do SRAA (BROWN et al., 2007). A baixa perfusão renal ou a redução da TFG promovem a redução do fluxo urinário, o que é detectado pelas células da mácula densa, que, por sua vez, estimulam as células granulares para produção e secreção de renina. Como citado no item 2.2.2, a liberação de renina é o passo inicial para ativação do SRAA.

As alterações laboratoriais mais comumente encontradas na DRC são:

- anemia não regenerativa: devido às perdas sanguíneas (hematoemese, melena) e diminuição da produção de eritropoetina pelos rins (McGROTTY, 2008);

- isostenúria: em consequência da lesão tubular e incapacidade em concentrar a urina (McGROTTY, 2008);

- proteinúria renal: a proteinúria persistente pode ser um indicativo de lesão renal, tanto pelo comprometimento da BFG, quanto do sistema tubular (GRAUER, 2007; POLZIN, 2007). Ainda na DRC, a hipoperfusão renal estimula a ativação do SRAA, que via angiotensina II, promove a vasoconstrição da arteríola eferente, o que resulta em hipertensão nos capilares glomerulares, dilatação dos poros da BFG e proteinúria (HARLEY; LANGSTON, 2012).

Ressalta-se que a proteinúria deve ser interpretada com muito critério pelo clínico veterinário, uma vez que: 1) os cães podem apresentar proteinúria em condições normais; 2) falsos negativos podem ser obtidos com o uso de fitas reagentes na urinálise; 3 ) inflamação ou hemorragia do trato urinário promove a marcação para proteínas nas fitas reagentes; 4) outras condições provocam proteinúria, como a doença cardiovascular e as neoplasias; 5) devem-se priorizar os métodos quantitativos, já que na DRC a proteinúria pode ser variável ao longo do tempo; e 6) em cães, a proteinúria é considerada persistente após a sua detecção em três ou mais momentos distintos, com intervalo de pelo menos duas semanas (GRAUER, 2017).

- azotemia: resultante da baixa TFG (VANHOLDER et al., 2008); 
- hiperfosfatemia: o fósforo é excretado pela urina, por meio da filtração glomerular. A baixa TFG na DRC resulta em hiperfosfatemia. Esta condição leva ao aumento da atividade sérica do paratormônio, que é considerado uma toxina urêmica capaz de causar alterações orgânicas, além de ser o principal responsável pelo desequilíbrio no metabolismo de cálcio em cães com DRC (CORTADELLAS et al., 2010);

- acidose metabólica: decorrente da incapacidade renal de excretar hidrogênio, fosfato e sulfato e pela diminuição de reabsorção tubular de bicarbonato (McGROTTY, 2008).

No exame ultrassonográfico de um cão com DRC, as principais alterações observadas são aumento da ecogenicidade cortical, perda do limite corticomedular, redução do volume renal e contorno irregular, sendo que quando se encontram associadas indicam uma doença renal terminal (BRAGATO; BORGES; FIORAVANTI, 2017).

\subsubsection{Estadiamento da DRC}

De acordo com a International Renal Interest Society (IRIS), a DRC é classificada em quatro estádios, conforme a concentração sérica de creatinina (IRIS, 2017). Este estadiamento é apresentado no Quadro 1.

Quadro 1 - Estadiamento da doença renal crônica

\begin{tabular}{|c|c|}
\hline Estádio & Concentração sérica de creatinina (mg/dL) \\
\hline $\mathbf{1}$ & Até 1,4 \\
\hline $\mathbf{2}$ & Entre 1,4 e 2,0 \\
\hline $\mathbf{3}$ & Entre 2,1 e 5,0 \\
\hline $\mathbf{4}$ & Acima de 5,0 \\
\hline
\end{tabular}

Fonte: IRIS (2017).

A IRIS também propõe a avaliação da dimetil arginina simétrica (denominada SDMA) que é um produto da metilação intranuclear de resíduos da L-arginina, liberado na circulação sanguínea, após a proteólise. Assim como acontece com a creatinina, a SDMA é eliminada pela urina, por meio da filtração glomerular, e por isso estes dois metabólitos são considerados marcadores endógenos da função renal (BRAFF et al., 2014). Segundo a IRIS (2017), a determinação da concentração plasmática ou sérica da SDMA pode auxiliar no diagnóstico e estadiamento da DRC (IRIS, 2017). Cães com creatinina abaixo de 1,4 mg/dL, 
mas aumento persistente na concentração de SDMA (acima de $14 \mathrm{ug} / \mathrm{dL}$ ) podem ser classificados no estádio 1. Cães no estádio 2, mas com SDMA acima de $25 \mathrm{ug} / \mathrm{dL}$, podem ser reclassificados para o estádio 3 e cães no estádio 3, mas com SDMA acima de 45 ug/dL, podem ser reclassificados para o estádio 4 (IRIS, 2017).

Também são propostos subestadiamentos, baseados na proteinúria e no valor da pressão arterial sistólica (PAS), conforme descrição apresentada no Quadro 2.

Quadro 2 - Subestadiamento da doença renal crônica

\begin{tabular}{|c|c|}
\hline Subestádio & Valor da relação creatinina/proteína urinárias \\
\hline Não proteinúrico & Menor que 0,2 \\
\hline Proteinúrico limítrofe & Entre 0,2 a 0,4 \\
\hline Proteinúrico & Acima de 0,4 \\
\hline Subestádio & Valor da pressão arterial sistólica (mmHg) \\
\hline Normotenso & $<140$ \\
\hline Pré-hipertenso & Entre $140-159$ \\
\hline Hipertenso & Entre $160-179$ \\
\hline Hipertenso Severo & $\geq 180$ \\
\hline
\end{tabular}

Fonte: IRIS (2017).

Esta classificação auxilia o clínico veterinário no diagnóstico e tratamento de cães com DRC.

\subsubsection{Tratamento da DRC}

Os pontos principais do tratamento, segundo a IRIS (2017), se baseiam no:

- controle da volemia: em casos de desidratação utilizar fluidos de reposição isotônica ou poliiônicas como, por exemplo, o ringer com lactato, por via subcutânea ou intravenosa, de acordo com o quadro clínico do paciente;

- manutenção do equilíbrio ácido-base: em casos de acidose metabólica é recomendada a administração oral ou parenteral de bicarbonato de sódio;

- modificações na dieta: as dietas coadjuvantes para cães com DRC apresentam quantidade moderada de proteínas, o que reduz a formação de toxinas urêmica; baixo teor de sódio, para auxiliar no controle da PAS, e de fósforo; 
- correção da anemia: fornecendo aporte nutricional e minimizando os efeitos da uremia, principalmente, sobre as perdas sanguíneas gastrointestinais. Pacientes em estádio 3 ou 4, apresentando hematócrito abaixo de 20\%, recomenda-se a administração da eritropoetina recombinante humana para estimular a medula óssea;

- e uso de medicamentos como quelantes de fósforo (hidróxido de alumínio), antieméticos (metoclopramida ou citrato de maropitant), protetores de mucosa gástrica (ranitidina ou omeprazol) e anti-hipertensivos (inibidores da enzima conversora de angiotensina II, bloqueadores de canais de cálcio, bloqueadores do receptor tipo I da angiotensina II e/ou hidralazina). Os anti-hipertensivos também são indicados para o controle da proteinúria, principalmente, quando a relação proteína/creatinina $(\mathrm{Pu} / \mathrm{C})$ urinária for maior do que 1. Para Vaden e Elliott (2016), valores de $\mathrm{Pu} / \mathrm{C}$ acima de 1 podem aumentar em três vezes o risco de crise urêmica e morte em cães.

\subsection{PODOCITÚRIA E DRC}

Os podócitos são fundamentais para a manutenção da estrutura e função da BFG; contudo, apresentam baixa regeneração e são extremamente sensíveis ao estresse celular, de modo que, facilmente, perdem a sua integridade estrutural (inclusive, os processos podais), entram em processo de desdiferenciação, apoptose e desprendimento (o que induz à podocitúria); comprometendo a BFG e ocasionando a doença renal progressiva, caracterizada, entre outros fatores, pela proteinúria (MOSQUERA, 2013; MATAVELLI, 2015).

O desprendimento dos podócitos da membrana basal glomerular pode ocorrer em condições fisiológicas ou devido à elevação das tensões mecânicas, relacionadas à hipertensão, hiperfiltração glomerular e doenças glomerulares degenerativas, que, por sua vez, alteram o citoesqueleto do podócito (KRIZ; LEMLEY, 2015).

As alterações podocitárias podem ser identificadas por meio da análise histológica do tecido renal; entretanto, a detecção de podocitúria tem sido considerada um método adicional para avaliar a proteinúria relacionada ao dano à BFG. A este respeito, Yu et al. (2005) propuseram que a podocitúria poderia ser mais precisa do que a proteinúria para identificar alterações na BFG. Segundo Trimarchi (2017), a podocitúria é um dos eventos iniciais da DRC, sendo responsável pela podocitopenia e consequente proteinúria. Esta afirmação é consistente com a perda do processo podal, desprendimento de podócitos e podocitopenia identificados na biópsia renal de cães em diferentes estágios da DRC (ICHII et al., 2011) e com DRC proteinúrica (HOKAMP et al., 2018). 
Os podócitos que se desprendem da membrana basal são eliminados pela urina, porém essas células só serão caracterizadas no sedimento urinário por meio de marcadores específicos, como a podocina, a podocalixina (uma proteína localizada na membrana plasmática apical dos processos podais) e/ou a sinaptopodina (uma proteína associada ao citoesqueleto de actina do podócito) (TRIMARCHI, 2015; KOSTOVSKA et al., 2016). Esses componentes estruturais do podócito podem ser identificados pela marcação imunohistoquímica ou imunofluorescente e pela citometria de fluxo (KOSTOVSKA et al., 2016). Após a caracterização do podócito e contagem das células marcadas para podocina, podocalixina e/ou sinaptopodina, a podocitúria pode ser expressa pelo número total de podócitos em um determinado volume de urina ou em relação à concentração urinária de creatinina (SABINO et al., 2013).

A podocitúria já foi avaliada no sedimento urinário de roedores e humanos por meio da expressão do RNAm associado ao podócitos, utilizando-se a técnica de Polymerase Chain Reaction (PCR). Experimentos em ratos com doença renal induzida evidenciaram o aumento da excreção urinária do RNAm para nefrina (NPHS1) e podocina (NPHS2), acompanhado de proteinúria, na fase inicial da doença. Ao longo das semanas, a proteinúria persistiu, assim como a excreção do NPHS2 na urina dos ratos, porém o NPHS1 não foi mais detectado (SATO et al., 2009; FUKUDA et al., 2012). Esses autores relacionaram a proteinúria persistente e o aumento do NPHS2 na urina com a evolução da DRC. Esses resultados demonstram ainda que a nefrina e a podocina são marcadores para podocitúria em ratos, com expressão diferenciada, de acordo com a evolução da doença renal. O aumento de NPHS2 também foi observado no sedimento urinário de humanos com diferentes tipos de doenças glomerulares, como glomerulonefrite aguda, glomeruloesclerose segmentar focal e relacionada ao diabetes. Além disso, o alto risco de progressão da doença glomerular foi associado à alta excreção urinária do NPHS2 nesses pacientes (WICKMAN et al., 2013).

Estudos recentes sugerem que a lesão dos podócitos é o evento precoce mais importante para a glomeruloesclerose na DRC (CHEN et al., 2013; MOSQUERA, 2013). Além disso, alterações na expressão ou na função das proteínas do diafragma (nefrina e podocina) são importantes para a perda dos podócitos e proteinúria. Dessa forma, Chuang e He (2009) destacaram que a nefrina e podocina poderiam ser marcadores do desenvolvimento da doença renal, a partir da lesão dos podócitos e da BFG.

A expressão urinária do RNAm associado aos podócitos corresponde a um método não invasivo para avaliar a podocitúria e a integridade da BFG, servindo como uma ferramenta útil para o diagnóstico e acompanhamento da DRC em diversas espécies animais. Ichii et al. 
(2011) avaliaram o NPHS1 e o NPHS2 no sedimento urinário de cães com DRC (estágios 14); contudo, apenas o NPHS2 foi detectado. Esses autores também observaram baixa expressão de nefrina (RNAm e proteína), lesões podocitárias e podocitopenia no glomérulo, sugerindo uma relação entre a lesão na BFG, a podocitopenia, a podocitúria e a DRC em cães.

Em outro estudo, cães com DRC devido à leishmaniose visceral, apresentaram menor expressão urinária do NPHS1 nos estágios mais avançados da doença, em comparação aos estágios iniciais (TORRES et al., 2016). Nesta pesquisa, os autores não avaliaram a podocina. 


\section{HIPÓTESE}

A hipótese desta pesquisa é que o NPHS1 e NPHS2, diretamente relacionados às proteínas estruturais dos podócitos, podem ser detectados no sedimento urinário de cães hígidos e com DRC, mas com variação na expressão urinária entre os estádios iniciais e finais da doença. 


\section{OBJETIVO GERAL}

O objetivo deste estudo foi avaliar a expressão do RNAm relacionado aos podócitos no sedimento urinário de cães hígidos ou com DRC, procurando-se estimar e diferenciar a podocitúria fisiológica e a podocitúria associada à DRC nesta espécie.

\subsection{OBJETIVOS ESPECÍFICOS}

Os objetivos específicos deste estudo foram:

- Identificar e quantificar a expressão do NPHS1 e NPHS2 no sedimento urinário de cães hígidos e de cães com DRC;

- Correlacionar a expressão do NPHS1 e NPHS2 no sedimento urinário com os parâmetros utilizados no diagnóstico da DRC em cães;

- Avaliar a expressão do NPHS1 e NPHS2 no sedimento urinário de cães em estádios iniciais ou mais avançados da DRC. 


\section{MATERIAL E MÉTODOS}

\subsection{ANIMAIS}

Participaram desse estudo cães com ou sem DRC, de ambos os sexos, castrados ou não, de qualquer raça e com idade $\geq$ a 5 anos, provenientes da rotina de atendimentos da Unidade Didático Clínico Hospitalar (UDCH) da FZEA/USP.

Este protocolo experimental foi aprovado pelo Comitê de Ética no Uso de Animais da FZEA/USP (protocolo CEUA: 5180200917).

\subsection{AVALIAÇÃO CLÍNICA DOS CÃES}

Para a seleção dos cães, foi realizada uma avaliação criteriosa do histórico clínico, exame físico e exames complementares, visando à inclusão de cães hígidos e também com DRC.

\subsubsection{Exame físico}

Os cães foram avaliados por meio da inspeção das mucosas aparentes, tempo de preenchimento capilar (TPC) e prega da pele (para avaliação da hidratação); palpação dos linfonodos, do pulso arterial (artéria femoral), do choque cardíaco (na região do precórdio) e do abdômen; auscultação cardiopulmonar e pesagem em balança digital (FEITOSA, 2008).

Os escores de condição corporal (ECC) e de massa muscular (EMM) também foram determinados por meio da inspeção e palpação (LAFLAMME, 1997; BALDWIN, et al., 2010).

\subsubsection{Exames complementares}

Os exames laboratoriais que fizeram parte da avaliação dos cães constam no Quadro 3. Estes exames foram realizados para o recrutamento dos cães hígidos e confirmação do diagnóstico nos cães com DRC.

As amostras de sangue foram coletadas por punção venosa, após 8 a 12 horas de jejum e o soro sanguíneo foi obtido por centrifugação. A coleta de urina foi realizada por micção 
espontânea ou cateterização. Os rins e as vias urinárias foram inspecionados por meio da ultrassonografia abdominal.

Quadro 3 - Descrição dos exames laboratoriais

\begin{tabular}{|c|c|}
\hline $\begin{array}{c}\text { Exames } \\
\text { laboratoriais }\end{array}$ & Parâmetros \\
\hline $\begin{array}{c}\text { Hemograma } \\
\text { completo }^{1}\end{array}$ & Eritrograma, leucograma e contagem de plaquetas. \\
\hline $\begin{array}{l}\text { Perfil bioquímico }{ }^{2} \mathrm{e} \\
\text { eletrolítico sérico }^{3}\end{array}$ & $\begin{array}{l}\text { [creatinina] e [ureia]. } \\
\text { [PT] e [ALB]. } \\
\text { [sódio], [potássio] e [cálcio ionizado]. }\end{array}$ \\
\hline Urina tipo I & Análise física, química e do sedimento. \\
\hline $\begin{array}{l}\text { Relação } \\
\text { proteína/creatinina } \\
\text { urinária }^{2}(\mathrm{Pu} / \mathrm{C})\end{array}$ & [proteína total] e [creatinina]. \\
\hline
\end{tabular}

Nos cães com DRC avaliou-se também a concentração sérica de fósforo e cálcio total, utilizando-se kits laboratoriais comerciais e espectrofotometria.

5.2.3 Mensuração da pressão arterial (PA) não invasiva

O manguito (de largura referente a $40 \%$ da circunferência do membro) foi colocado sempre no membro torácico esquerdo, sobre o terço proximal da região radio-ulnar. Após a obtenção dos sinais de pulso adequados, com o transdutor do doppler vascular portátil (10 MHz, DV 610V MEDMEGA®, Brasil) (Figura 5), o manguito foi inflado até a obliteração do sinal de pulso audível e, em seguida, lentamente desinflado. A PA sistólica foi determinada quando o sinal de pulso se tornou audível novamente (CABRAL et al., 2010). Foram realizadas pelo menos três medidas consecutivas da PA em cada animal, para a obtenção de um valor médio representativo (ACIERNO; LABATO, 2005). 
Figura 5 - Mensuração da pressão arterial sistólica em um cão do estudo

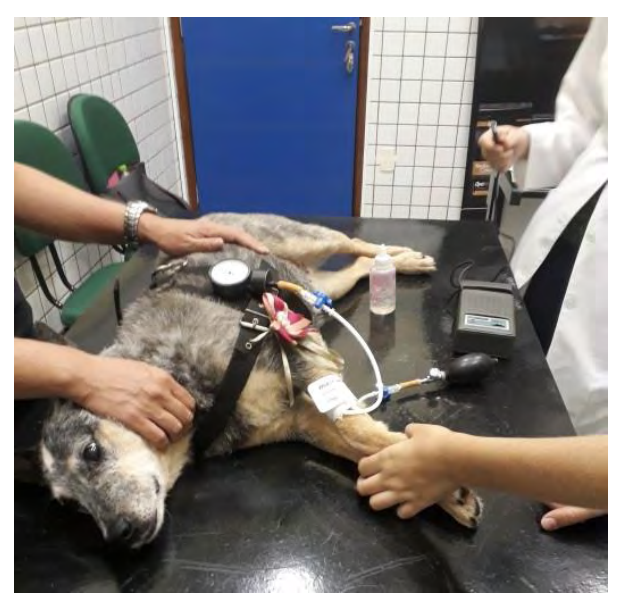

Australian Cattle Dog, 12 anos, fêmea, posicionada em decúbito lateral direito para o exame. Fonte: Própria autoria.

\subsection{GRUPOS EXPERIMENTAIS}

De acordo com o resultado dos exames e o estadiamento da DRC, os cães foram divididos em 3 grupos:

- Grupo controle: formado por cães hígidos, sem qualquer sinal de doença renal.

- Grupo DRC 1-2: formado por cães com características da DRC em estádios 1 e 2.

- Grupo DRC 3-4: formado por cães com manifestações clínicas da DRC e características dos estádios 3 ou 4.

\subsubsection{Critérios de exclusão}

Não foram incluídos nesta pesquisa os cães com início súbito de doença renal (há menos de 3 meses) e com histórico recente de intoxicação, hipovolemia ou hipotensão; ou seja, aqueles que se enquadrarem no diagnóstico de lesão renal aguda. Além disso, a fim de excluir as causas de proteinúria pré ou pós-renal, cães com alterações metabólicas relacionadas às hepatopatias e doenças endócrinas, doenças concomitantes (infectocontagiosas e neoplásicas) e inflamação/infecção do trato urinário não participaram da pesquisa. Os exames laboratoriais foram realizados nos cães em estado normal de hidratação e estáveis em relação à DRC. 


\subsection{EXTRAÇÃO DO RNA DO SEDIMENTO URINÁRIO DOS CÃES}

Para esta análise, as amostras de urina foram coletadas e preservadas a $-80{ }^{\circ} \mathrm{C}$. Posteriormente, o RNA total foi extraído utilizando o reagente Trizol (Thermo Fisher Scientific, EUA), associado com o glicogênio e o acetato de sódio de acordo com o proposto por Monteiro et al. (2016). Para isso, as amostras eram descongeladas e centrifugadas a $3.000 \mathrm{~g}$ por 30 minutos a $4^{\circ} \mathrm{C}$. O sobrenadante foi então descartado e foi adicionado $1 \mathrm{~mL}$ de Trizol e $1 \mu \mathrm{L}$ de glicogênio em cada tubo. As amostras foram levadas ao vortex e depois incubadas por 5 minutos em temperatura ambiente. Após isso, $200 \mu \mathrm{L}$ de clorofórmio foram adicionados em cada tubo, que novamente foram submetidos ao vortex e incubados por mais 5 minutos em temperatura ambiente. Depois, as amostras foram centrifugadas por $10.000 \mathrm{~g}$ por 15 minutos a $4^{\circ} \mathrm{C}$. Logo após a centrifugação, 3 fases foram observadas. $\mathrm{O}$ volume da fase aquosa e incolor, onde estava presente o RNA, foi pipetado para outro tubo e um volume de álcool isopropílico e $100 \mu \mathrm{L}$ de acetato de sódio foram adicionados. Após isso, as amostras foram colocadas no gelo por 30 minutos e, posteriormente, centrifugadas a $10.000 \mathrm{~g}$ por 20 minutos a $4{ }^{\circ} \mathrm{C}$ para precipitação do RNA. O sobrenadante foi então descartado e o pellet, ressuspendido com $1 \mathrm{~mL}$ de álcool etílico 70\%. Os tubos contendo o pellet ressuspendido foram levados ao vortex e depois centrifugados a $10.000 \mathrm{~g}$ por 10 minutos a $4{ }^{\circ} \mathrm{C}$. Esta etapa foi realizada duas vezes. O sobrenadante foi então descartado, e o pellet ressuspendido em 35 $\mu \mathrm{L}$ de água livre de RNAse para ser utilizado na síntese de cDNA. A quantidade e qualidade do RNA extraído foram analisadas pelo equipamento NanoDrop 2000 (Thermo Fisher Scientific, EUA) e por eletroforese em gel de agarose. Foram consideradas apropriadas para uso, as amostras que apresentaram razão 260/280 entre 1,0 e 2,0 e bandas ribossomais 18s e 28s íntegras no gel de agarose, em comparação a uma amostra controle de RNA total isolado de células de pulmão de camundongo.

\subsubsection{Tratamento com DNAse}

Após a quantificação, a concentração de RNA de cada amostra foi ajustada para 1000 $\mathrm{ng} / \mu \mathrm{L}$ e depois as amostras foram tratadas com DNAse para a degradação de possíveis fragmentos de DNA, da seguinte maneira: adicionou-se o buffer DNAse 10x em uma concentração de $1 \mathrm{x}$ e $0,5 \mu \mathrm{l}$ de DNAse do tipo I e livre de RNAse (Ambion- Life Technologies, EUA), depois, as amostras foram incubadas no termociclador (Termociclador T100 - Bio-rad, EUA) por 30 minutos a $37^{\circ} \mathrm{C}$. Logo após, a temperatura foi elevada a $75{ }^{\circ} \mathrm{C}$ 
por 10 minutos, com o objetivo de inativar a DNAse. Nesta etapa, o EDTA foi adicionado em uma concentração de $5 \mathrm{mM}$, para evitar a degradação do RNA como consequência da alta temperatura.

\subsection{SÍNTESE DO cDNA}

Os RNAm foram transcritos reversamente para cDNA utilizando o kit Hight Capacity cDNA Reverse Transcription (Thermo Fisher Scientific, EUA). A reação foi padronizada para um volume de $20 \mu \mathrm{L}$ com uma concentração final de $50 \mathrm{ng} / \mu \mathrm{L}$. Desses $20 \mu \mathrm{L}, 2 \mu \mathrm{L}$ era de RT buffer 10X, 0,8 $\mu \mathrm{l}$ de dNTP mix 25X, $2 \mu \mathrm{L}$ de RT random primers $10 \mathrm{X}, 1 \mu \mathrm{L}$ da enzima transcriptase reversa MultiScribe (Thermo Fisher Scientific, EUA), $1 \mu \mathrm{L}$ do RNA total, e completava-se a reação com água livre de RNAse para um total de $20 \mu \mathrm{L}$. Após isso, as amostras eram levadas ao termociclador (Termociclador T100 - Bio-rad, EUA) e incubadas a $25^{\circ} \mathrm{C}$ por 10 minutos, $37^{\circ} \mathrm{C}$ por 2 horas e a $75^{\circ} \mathrm{C}$ por 5 minutos, para a inativação da reação. As amostras eram armazenadas a $-20^{\circ} \mathrm{C}$, até o momento de sua utilização nas reações de PCR.

\subsection{AVALIAÇÃO E QUANTIFICAÇÃO DA EXPRESSÃO DO NPHS1 E NPHS2 POR PCR EM TEMPO REAL}

A análise de expressão de gênica foi feita por PCR em tempo real, utilizando o equipamento StepOne Real Time PCR (Applied Biosystems, EUA). O volume total das reações foi de $20 \mu \mathrm{l}$, sendo $10 \mu \mathrm{L}$ do reagente Fast SYBR Green Master Mix (Applied BioSystem, EUA), $1 \mu \mathrm{L}$ do respectivo primer a $100 \mathrm{nM}, 3 \mu \mathrm{l}$ de cDNA e o restante completado com água livre de RNAses. A reação foi feita com 1 ciclo de 20 segundos a $95^{\circ} \mathrm{C}$ e 40 ciclos de 3 segundos a $95^{\circ} \mathrm{C}$ e 30 segundos a $60^{\circ} \mathrm{C}$. Foram utilizados os primers descritos na Tabela 1. O primer NPHS2 foi desenhado em regiões distintas de dois éxons diferentes, de maneira que houvesse uma região de íntrons entre eles, com o objetivo de evitar resultados falsos positivos decorrentes da amplificação de DNA genômico. Para o desenho do primer, foi usado o programa Primer-BLAST (YE, et al., 2012). Para o primer NPHS1 utilizou-se a sequência proposta por Ichii et al. (2011). Os primers foram testados em PCR In Silico, disponível na plataforma UCSC Genome Bioinformatics. A expressão ribossomal 18s foi utilizada como gene endógeno e normalizador das reações. Como controle positivo foi utilizado um fragmento de rim de cão. Em cada amostra, a detecção do RNAm dos alvos foi estabelecida com base no CT do controle negativo e apresentada em porcentagem. As 
diferenças entre a expressão do RNAm dos alvos e endógeno foram calculadas utilizando o método 2DDCT (LIVAK; SCHMITTGEN, 2001). Os resultados da expressão relativa dos RNAm foram apresentados em relação ao controle, na base de log e padronizados pela concentração da creatinina urinária.

Tabela 1 - Primers utilizados na realização do PCR em tempo real

\begin{tabular}{ll}
\hline \multicolumn{1}{c}{ Primers } & \multicolumn{1}{c}{ Sequências $\left(5^{\prime}-3^{\prime}\right.$ ') } \\
\hline NPHS1 sense & CCTGTATGATGAAGTGGAAAGG \\
NPHS 1 antissense & AGGGTCCAAGTTTCCTGCTAC \\
NPHS2 sense & GGTTTAGGGGCCTGTGAGTG \\
NPHS2 antissense & AGCAGATGTCCCAGTCGAAA \\
18S sense & CCTGCGGCTTAATTTGACTC \\
18S antissense & CTGTCAATCCTGTCCGTGTC
\end{tabular}

Fonte: Própria autoria.

\subsection{PADRONIZAÇÃO DA TÉCNICA DE PCR}

Após o processo de amplificação, as curvas de Melting (ou curvas de dissociação) foram avaliadas com a finalidade de verificar a especificidade do produto de PCR amplificado para cada primer. A curva de Melting representa a relação entre a temperatura (eixo x) e a quantidade de emissão de fluorescência da reação de PCR (eixo Y), sendo que o ideal é a observação de apenas um pico em cada curva. A eficiência da reação de PCR foi verificada a partir da curva padrão.

\subsection{ORGANOGRAMA}

Este estudo foi realizado de acordo com o organograma apresentado na Figura 6. 
Figura 6 - Organograma para avaliação dos cães e realização das análises

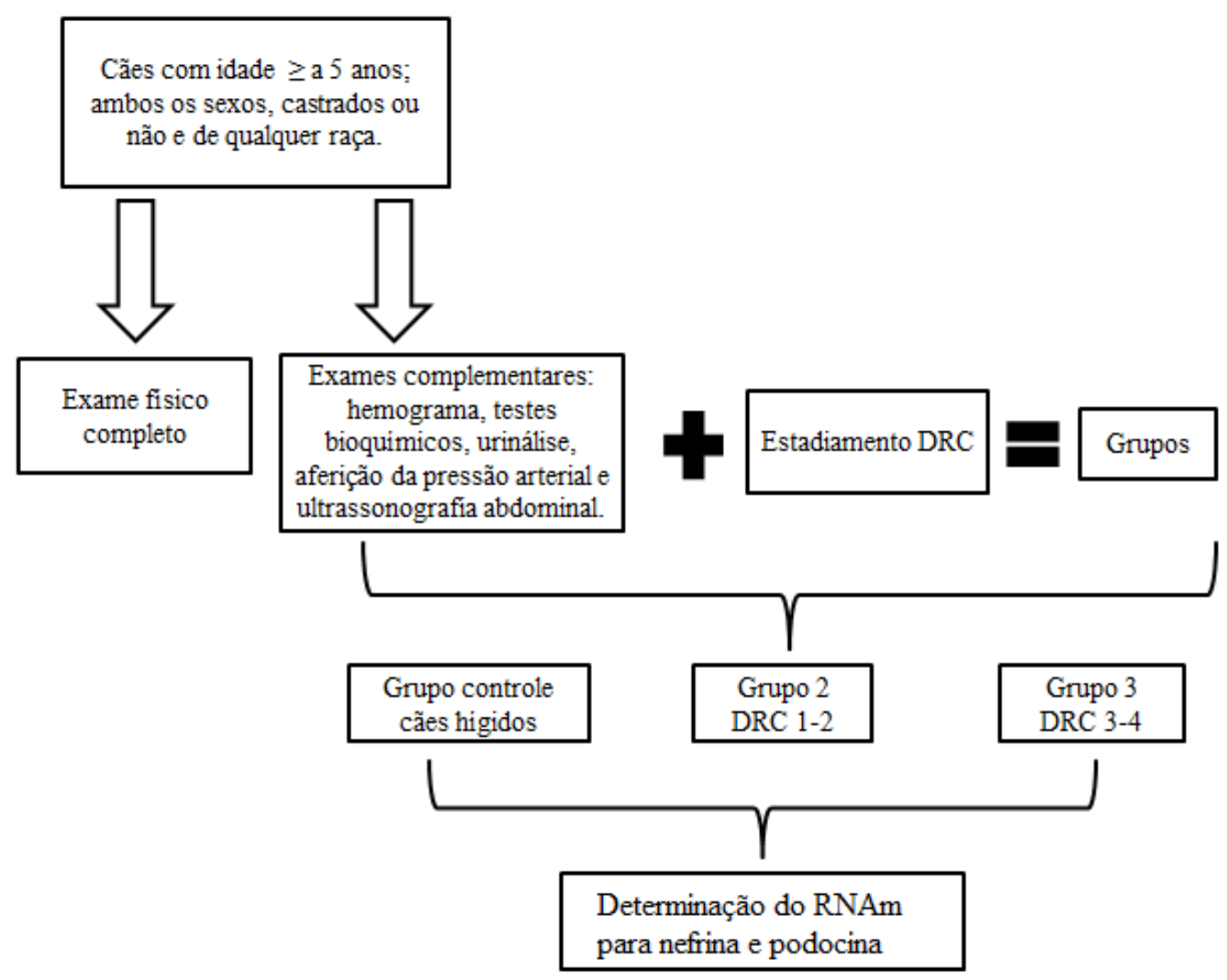

DRC $=$ Doença renal crônica.

Fonte: Própria autoria.

\subsection{ANÁLISES ESTATÍSTICAS}

Os valores médios foram apresentados com seus respectivos erros padrão. O experimento foi realizado em um delineamento inteiramente casualizado com três tratamentos e 10 repetições para o tratamento controle, 5 repetições para o tratamento $\mathrm{DRC}_{1-2}$ e 9 repetições para o tratamento $\mathrm{DRC}_{3-4}$, sendo cada animal considerado uma unidade experimental. Os parâmetros avaliados foram testados em relação a sua normalidade utilizando o teste Shapiro Wilk e, quando necessário, foram normalizados pela transformação logarítmica na base 10 para que se realizasse a análise de variância (ANOVA). Quando verificado efeito significativo, as médias foram comparadas pelo teste T de Student com nível de significância de 5\%. A porcentagem de detecção do RNAm foi comparada entre os grupos pelo Teste qui-quadrado. Além disso, o procedimento CORR foi utilizado para determinar os coeficientes de correlação de Pearson entre os diferentes parâmetros avaliados. As análises estatísticas foram feitas utilizando o procedimento MIXED do Software SAS modelo 9.4 (SAS Institute Inc., EUA). 


\section{RESULTADOS}

\subsection{CARACTERIZAÇÃO DOS GRUPOS EXPERIMENTAIS}

Neste estudo foram avaliados um total de 30 cães adultos e idosos, principalmente, devido ao histórico de poliúria e polidipsia persistentes. Destes, 14 foram diagnosticados com DRC em diferentes estádios. Outros 10 cães hígidos foram recrutados para formar o grupo controle. As informações sobre raça, sexo e idade dos cães que participaram deste estudo são apresentadas na Tabela 1.

O grupo controle foi formado, majoritariamente, por cães sem raça definida (90\%) e pelo mesmo número de machos e fêmeas. Já no grupo DRC, houve predomínio de cães com raça $(71,4 \%)$ e fêmeas $(71,4 \%)$. Os grupos controle e $\mathrm{DRC}$ não diferiram quanto à idade $(\mathrm{P}=$ 0,22 ), sendo que a maioria dos cães destes grupos tinha idade igual ou superior a 8 anos $(60,0 \%$ e $85,7 \%$, respectivamente) (Tabela 2$)$.

Tabela 2 - Raça, idade e sexo dos cães selecionados para o projeto

\begin{tabular}{c|ccc|ccc}
\hline & \multicolumn{3}{|c|}{ Controle (n=10) } & \multicolumn{3}{c}{ DRC (n=14) } \\
Cães & Raças & Idade (anos) & Sexo & Raças & Idade (anos) & Sexo \\
\hline $\mathbf{1}$ & Dachshund & 12 & M & Cocker Spaniel & 14 & M \\
$\mathbf{2}$ & SRD & 6 & M & Pitbull & 9 & M \\
$\mathbf{3}$ & SRD & 6 & M & SRD & 11 & M \\
$\mathbf{4}$ & SRD & 6 & M & Yorkshire & 9 & M \\
$\mathbf{5}$ & SRD & 9 & M & Australian Cattle Dog & 12 & F \\
$\mathbf{6}$ & SRD & 7 & F & Beagle & 12 & F \\
$\mathbf{7}$ & SRD & 8 & F & Boxer & 12 & F \\
$\mathbf{8}$ & SRD & 10 & F & Bulldog & 13 & F \\
$\mathbf{9}$ & SRD & 11 & F & Cocker Spaniel & 17 & F \\
$\mathbf{1 0}$ & SRD & 14 & F & Dogue Alemão & 6 & F \\
$\mathbf{1 1}$ & --- & --- & --- & Labrador Retriever & 5 & F \\
$\mathbf{1 2}$ & --- & --- & --- & SRD & 11 & F \\
$\mathbf{1 3}$ & --- & --- & --- & SRD & 12 & F \\
$\mathbf{1 4}$ & --- & --- & --- & SRD & 14 & F \\
\hline Médias & --- & $8,9 \pm 0,89 a$ & --- & --- & $11,21 \pm 0,84 a$ & --- \\
\hline
\end{tabular}

$\mathrm{DRC}=$ doença renal crônica; $\mathrm{n}=$ número de animais por grupo; $\mathrm{SRD}=$ sem raça definida; $\pm=$ erro padrão. Letras iguais na mesma linha indicam que não houve diferença entre os valores médios. Fonte: Própria autoria.

A partir dos valores da concentração sérica de creatinina e das orientações da IRIS (2017), os cães do grupo DRC foram subdivididos nos grupos $\mathrm{DRC}_{1-2}(\mathrm{n}=5)$ e $\mathrm{DRC}_{3-4}(\mathrm{n}=9)$. 
A partir deste momento, os resultados serão apresentados para os seguintes grupos experimentais: controle, $\mathrm{DRC}_{1-2}$ e $\mathrm{DRC}_{3-4}$.

\subsection{AVALIAÇÃO CLÍNICA}

\subsubsection{Exame físico}

Ao exame físico, todos os cães do grupo controle e os $\mathrm{DRC}_{1-2}$ apresentaram mucosas, hidratação e hálito normais, enquanto os cães do grupo $\mathrm{DRC}_{3-4}$ apresentaram mucosas hipocoradas $(55,6 \%)$, desidratação $(11,1 \%)$ e hálito urêmico $(11,1 \%)$. Nos três grupos, a maioria dos cães apresentava ECC ideal (5/9). Nos cães dos grupos $\mathrm{DRC}_{1-2}$ e $\mathrm{DRC}_{3-4}$, a maior parte dos cães apresentava discreta perda de massa muscular (EMM 2/3).

Os valores médios do peso corporal ECC e EMM constam da Tabela 3. Não houve diferença entre os grupos em relação ao peso corporal e $\operatorname{ECC}(P=0,111$ e 0,895, respectivamente); entretanto, o valor médio do $\mathrm{EMM}$ foi menor dos grupos $\mathrm{DRC}_{1-2}$ e $\mathrm{DRC}_{3-4}$ ( $\mathrm{P}<0,05)$, em comparação ao grupo controle.

Tabela 3 - Valores médios do peso corporal, ECC e EMM dos grupos experimentais

\begin{tabular}{cccc}
\hline Parâmetros & Controle $(\mathbf{n = 1 0})$ & DRC $_{\mathbf{1 - 2}}(\mathbf{n = 5})$ & $\mathbf{D R C}_{\mathbf{3 - 4}}(\mathbf{n = 9})$ \\
\hline Peso $(\mathbf{k g})$ & $10,2 \pm 3,00 \mathrm{a}$ & $19,8 \pm 3,17 \mathrm{a}$ & $14,5 \pm 4,25 \mathrm{a}$ \\
ECC & $5,6 \pm 0,46 \mathrm{a}$ & $5,6 \pm 0,65 \mathrm{a}$ & $5,9 \pm 0,49 \mathrm{a}$ \\
EMM & $3,0 \pm 1,14 \mathrm{a}$ & $\mathbf{2 , 0} \pm \mathbf{0 , 2 0 b}$ & $\mathbf{1 , 7} \pm \mathbf{0 , 1 5 b}$
\end{tabular}

$\mathrm{ECC}=$ escore de condição corporal; $\mathrm{EMM}=$ escore de massa muscular; $\overline{\mathrm{DRC}}=$ doença renal crônica nos estádios $1-2$ ou $3-4 ; n=$ número de cães por grupo; $\pm=$ erro padrão. Letras diferentes na mesma linha representam a diferença entre os valores médios. ${ }^{\mathrm{b}} \mathrm{P}<0,05$ versus grupo controle.

Fonte: Própria autoria.

\subsubsection{Pressão arterial sistólica (PAS)}

No grupo controle, nove cães $(90,0 \%)$ apresentaram o valor da PAS $<140 \mathrm{mmHg}$ e um $(10,0 \%)$ entre 140 e $159 \mathrm{mmHg}$. No grupo $\mathrm{DRC}_{1-2}$, quatro cães $(80 \%)$ apresentaram o valor da PAS < 140 mmHg e um (20,0\%) entre 140 e 159 mmHg. No grupo $\mathrm{DRC}_{3-4}$, três cães $(33,3 \%)$ apresentaram o valor da PAS < $140 \mathrm{mmHg}$, cinco $(55,6 \%)$ entre 140 e $159 \mathrm{mmHg}$ e um $(11,1 \%) \geq 180 \mathrm{mmHg}$. 
$\mathrm{O}$ valor médio da PAS foi maior no grupo $\mathrm{DRC}_{3-4}$, quando comparado aos grupos controle $(\mathrm{P}<0,05)$ e $\mathrm{DRC}_{1-2}(\mathrm{P}=0,028)$ (Figura 7$)$.

Figura 7 - Valores médios de pressão arterial sistólica (PAS) nos grupos experimentais

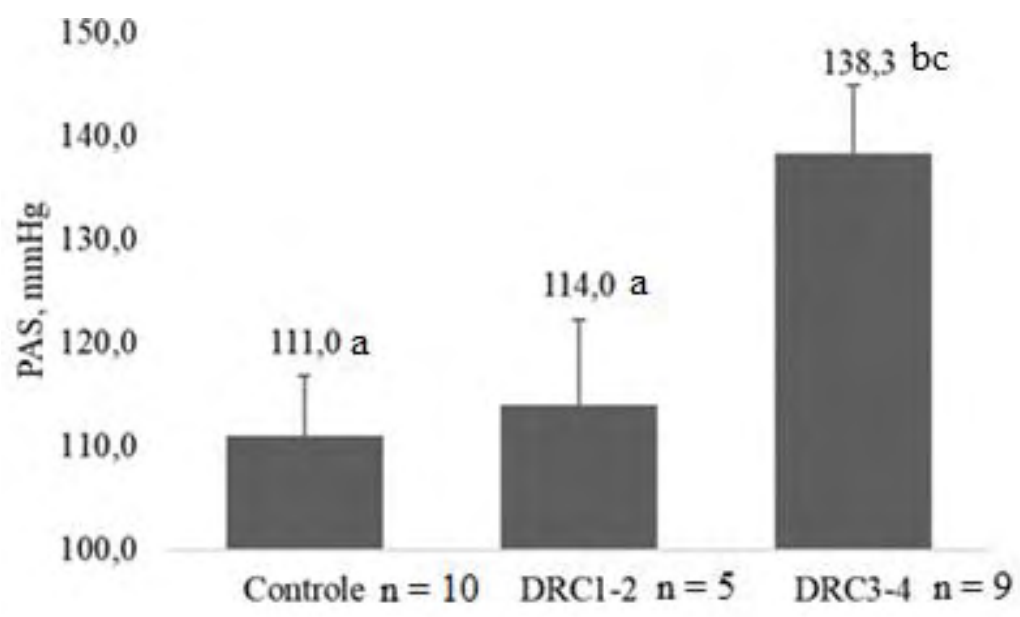

DRC $=$ doença renal crônica nos estádios $1-2$ ou 3-4; $n$ = número de cães por grupo. Letras diferentes nas barras representam a diferença entre os valores médios. ${ }^{b} \mathrm{P}<0,05$ versus grupo controle. ${ }^{c} \mathrm{P}<0,05$ versus grupo $\mathrm{DRC}_{1-2}$. Valores de referência até $150 \mathrm{mmHg}$ (Brown et al., 2007). Fonte: Própria autoria.

\subsubsection{Exames laboratoriais}

\subsubsection{Eritograma, contagem de plaquetas e leucócitos}

No grupo $\mathrm{DRC}_{3-4}$, os valores médios da contagem de eritrócitos, da concentração de hemoglobina e do hematócrito foram inferiores aos grupos controle e $\mathrm{DRC}_{1-2}(\mathrm{P}<0,05)$ e aos valores de referência (THRALL et al., 2015), uma vez que 55,6\% dos cães do grupo $\mathrm{DRC}_{3-4}$ apresentavam anemia normocítica normocrômica. Não foram observadas diferenças entre os grupos em relação aos índices hematimétricos (VCM, HCM e CHCM), contagem de plaquetas e de leucócitos (Tabela 4). 
Tabela 4 - Valores médios do eritrograma, contagem de plaquetas e de leucócitos dos grupos experimentais

\begin{tabular}{|c|c|c|c|c|}
\hline Parâmetros & $\begin{array}{c}\text { Controle } \\
(\mathbf{n}=10)\end{array}$ & $\begin{array}{c}\text { DRC }_{1-2} \\
(n=5)\end{array}$ & $\begin{array}{c}\mathrm{DRC}_{3-4} \\
(\mathrm{n}=9)\end{array}$ & $\begin{array}{l}\text { Valores de } \\
\text { referência }^{1}\end{array}$ \\
\hline Eritrócitos & $6,7 \pm 0,35 \mathrm{a}$ & $6,7 \pm 0,49 a$ & $4,7 \pm 0,36 b c$ & $5,5-8,5 \times 10^{6} / \mu \mathrm{L}$ \\
\hline Hemoglobina & $17,3 \pm 0,83 a$ & $16,7 \pm 1,17 \mathrm{a}$ & $11,6 \pm 0,88 b c$ & $12-18 \mathrm{~g} / \mathrm{dL}$ \\
\hline Hematócrito & $50,1 \pm 2,49 a$ & $49,7 \pm 3,52 \mathrm{a}$ & $34,9 \pm 2,63 b c$ & $37-55 \%$ \\
\hline $\mathrm{VCM}$ & $75,2 \pm 1,49 a$ & $75,0 \pm 2,11 \mathrm{a}$ & $75,2 \pm 1,57 \mathrm{a}$ & $60-77 \mathrm{fL}$ \\
\hline HCM & $26,0 \pm 0,58 \mathrm{a}$ & $25,2 \pm 0,82 \mathrm{a}$ & $25,0 \pm 0,61 \mathrm{a}$ & $21-26 \mathrm{pg}$ \\
\hline СНCM & $34,6 \pm 0,44 \mathrm{a}$ & $33,7 \pm 0,62 \mathrm{a}$ & $33,2 \pm 0,47 a$ & $32-36 \%$ \\
\hline Plaquetas & $307 \pm 545,1 \mathrm{a}$ & $385 \pm 771,3 a$ & $378 \pm 575,5 \mathrm{a}$ & $200-500 / \mu \mathrm{L} \times 10^{3}$ \\
\hline Leucócitos & $7,1 \pm 9,50 \mathrm{a}$ & $8,8 \pm 1,35 a$ & $7,5 \pm 1,02 \mathrm{a}$ & $6-17 / \mu \mathrm{L} \times 10^{3}$ \\
\hline
\end{tabular}

DRC $=$ doença renal crônica nos estádios $1-2$ ou $3-4 ; \mathrm{n}=$ número de cães por grupo $; \pm=$ erro padrão; $\mathrm{VCM}=$ volume corpuscular médio; $\mathrm{HCM}=$ hemoglobina corpuscular média; $\mathrm{CHCM}=$ concentração hemoglobina corpuscular média. Letras diferentes na mesma linha representam a diferença entre os valores médios. ${ }^{\mathrm{b}} \mathrm{P}<0,05$ versus grupo controle. ${ }^{\mathrm{c}} \mathrm{P}<0,05$ versus grupo $\mathrm{DRC}_{1-2}$ e $\mathrm{DRC}_{3-4} .{ }^{\text {TThrall et al. }}$ (2015). Fonte: Própria autoria.

\subsubsection{Perfil bioquímico e eletrolítico}

Os parâmetros do perfil bioquímico e eletrolítico avaliados nos cães dos grupos experimentais constam da Tabela 5.

No grupo $\mathrm{DRC}_{3-4}$, observou-se maiores valores médios para a concentração sérica de ureia e creatinina, em relação aos grupos controle e $\mathrm{DRC}_{1-2}(\mathrm{P}<0,001)$, e muito acima dos valores de referência (THRALL et al., 2015).

O grupo $\mathrm{DRC}_{3-4}$ também apresentou menor concentração sérica de cálcio ionizado e maior concentração sérica de potássio, em comparação ao grupo controle $(\mathrm{P}<0,001)$. $\mathrm{O}$ valor médio do cálcio ionizado no grupo $\mathrm{DRC}_{3-4}$ também foi inferior à referência (DIBARTOLA, 2015).

Os três grupos não diferiram quanto à concentração sérica de PT, albumina e sódio. Os valores médios da concentração de cálcio total e fósforo séricos não foram diferentes entre grupos $\mathrm{DRC}_{1-2} \mathrm{e} \mathrm{DRC}_{3-4}$, mas a hiperfosfatemia foi evidenciada nestes grupos. 
Tabela 5 - Valores médios do perfil bioquímico e eletrolítico dos grupos experimentais

\begin{tabular}{lcccc}
\hline Parâmetros & $\begin{array}{c}\text { Controle } \\
(\mathbf{n = 1 0})\end{array}$ & $\begin{array}{c}\mathbf{D R C}_{\mathbf{1 - 2}} \\
(\mathbf{n = 5})\end{array}$ & $\begin{array}{c}\mathbf{D R C}_{\mathbf{3 - 4}} \\
(\mathbf{n = 9})\end{array}$ & $\begin{array}{c}\text { Valores de } \\
\text { referência }^{\mathbf{1}}\end{array}$ \\
\hline Ureia & $39,4 \pm 44,30 \mathrm{a}$ & $47,3 \pm 62,65 \mathrm{a}$ & $\mathbf{2 5 9 , 4} \pm \mathbf{4 6 , 7 0 b c}$ & $10-60 \mathrm{mg} / \mathrm{dL}$ \\
Creatinina & $1,1 \pm 0,38 \mathrm{a}$ & $1,0 \pm 1,94 \mathrm{a}$ & $\mathbf{7 , 4} \pm \mathbf{1 , 4 5 b c}$ & $0,5-1,6 \mathrm{mg} / \mathrm{dL}$ \\
PT & $7,5 \pm 0,26 \mathrm{a}$ & $7,8 \pm 0,37 \mathrm{a}$ & $8,2 \pm 0,28 \mathrm{a}$ & $5,3-7,7 \mathrm{~g} / \mathrm{dL}$ \\
Albumina & $3,2 \pm 0,16 \mathrm{a}$ & $2,8 \pm 0,23 \mathrm{a}$ & $2,7 \pm 0,20 \mathrm{a}$ & $2,3-3,8 \mathrm{~g} / \mathrm{dL}$ \\
Fósforo & --- & $9,6 \pm 1,27 \mathrm{a}$ & $10,0 \pm 0,95 \mathrm{a}$ & $2,8-6,1 / \mathrm{mg} / \mathrm{dL}$ \\
Cálcio total & ---- & $9,8 \pm 0,02 \mathrm{a}$ & $9,6 \pm 0,80 \mathrm{a}$ & $9,0-11,2 \mathrm{mg} / \mathrm{dL}$ \\
Cálcio ionizado & $1,1 \pm 0,93 \mathrm{a}$ & $1,2 \pm 0,93 \mathrm{a}$ & $\mathbf{0 , 9} \pm \mathbf{0 , 7 0 b}$ & $1,12-1,40 \mathrm{mmol} / \mathrm{L}$ \\
Sódio & $148 \pm 1,5 \mathrm{a}$ & $143 \pm 2,11 \mathrm{a}$ & $141 \pm 1,58 \mathrm{a}$ & $140-155 \mathrm{mmol} / \mathrm{L}$ \\
Potássio & $4,6 \pm 0,16 \mathrm{a}$ & $4,5 \pm 0,16 \mathrm{a}$ & $\mathbf{5 , 8} \pm \mathbf{0 , 1 2 b}$ & $3,5-5,8 \mathrm{mmol} / \mathrm{L}$
\end{tabular}

$\mathrm{DRC}=$ doença renal crônica nos estádios $1-2$ ou $3-4 ; n=$ número de cães por grupo; $\pm=$ erro padrão; $\mathrm{PT}=$ proteína sérica total. Letras diferentes na mesma linha representam a diferença entre os valores médios. ${ }^{\mathrm{b}} \mathrm{P}<0,05$ versus grupo controle. ${ }^{\mathrm{c}} \mathrm{P}<0,05$ versus grupo $\mathrm{DRC}_{1-2}$ e $\mathrm{DRC}_{3-4}$. ${ }^{\text {Thall }}$ et al. (2015); Dibartola (2015). Fonte: Própria autoria.

\subsubsection{Densidade urinária, $\mathrm{pH}$ da urina e PU/C}

Os valores médios da densidade urinária foram menores (Tabela 6), enquanto os valores médios da PU/C foram maiores nos grupos $\mathrm{DRC}_{1-2}$ e $\mathrm{DRC}_{3-4}(\mathrm{P}<0,05)$ (Figura 8), em comparação ao grupo controle. Os grupos não diferiram quanto ao pH urinário (Tabela 6). Nenhum dos cães apresentava sinais de inflamação do trato urinário, segundo a avaliação do sedimento urinário.

Tabela 6 - Valores médios da densidade e pH urinários dos grupos experimentais

\begin{tabular}{lcccc}
\hline Parâmetros & $\begin{array}{c}\text { Controle } \\
(\mathbf{n = 1 0})\end{array}$ & $\begin{array}{c}\mathbf{D R C}_{\mathbf{1 - 2}} \\
(\mathbf{n = 5})\end{array}$ & $\begin{array}{c}\mathbf{D R C}_{\mathbf{3 - 4}} \\
(\mathbf{n = 9})\end{array}$ & $\begin{array}{c}\text { Valores de } \\
\text { referência }^{\mathbf{1}}\end{array}$ \\
\hline Densidade & $1,037 \pm 35,4 \mathrm{a}$ & $\mathbf{1 , 0 2 1} \pm \mathbf{5 0 , 1 b}$ & $\mathbf{1 , 0 1 4} \pm \mathbf{3 7 , 3 b}$ & $1,015-1,045$ \\
pH & $6,5 \pm 0,37 \mathrm{a}$ & $6,4 \pm 0,52 \mathrm{a}$ & $5,9 \pm 0,39 \mathrm{a}$ & $5,5-7,5$
\end{tabular}

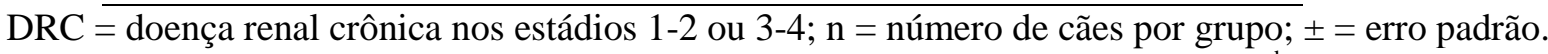
Letras diferentes na mesma linha representam a diferença entre os valores médios. ${ }^{\mathrm{b}} \mathrm{P}<0,05$ versus grupo controle. ${ }^{1}$ Thrall et al. (2015). Fonte: Própria autoria. 
Figura 8 - Valores médios de relação proteína/creatinina urinária (PU/C) nos grupos

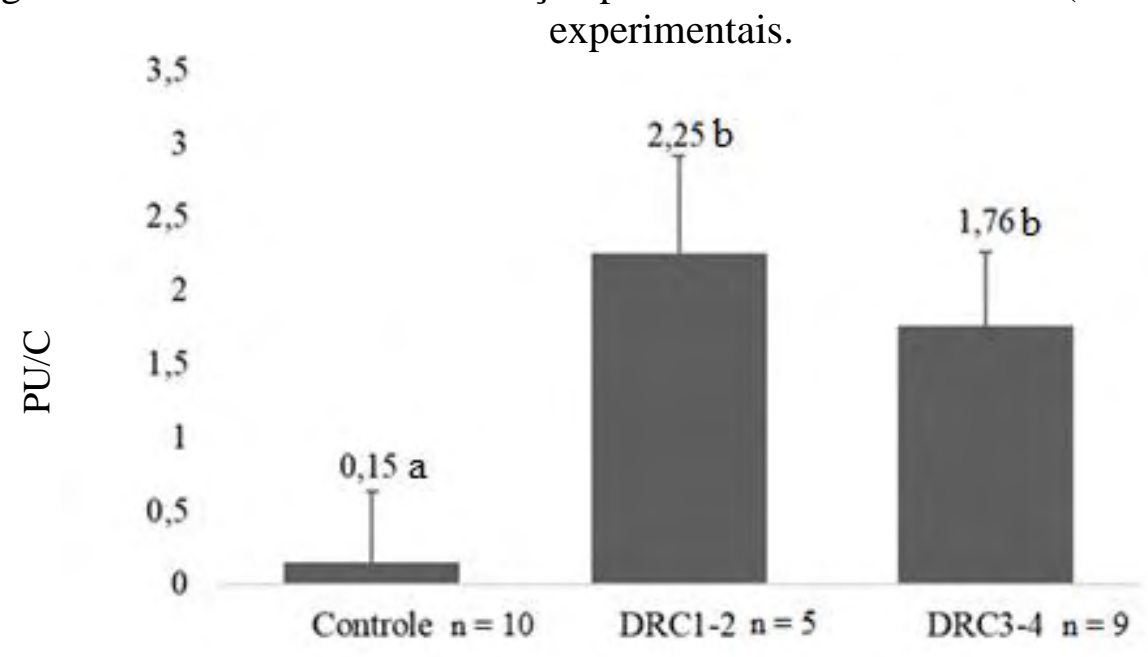

DRC $=$ doença renal crônica nos estádios 1-2 ou 3-4; $\mathrm{n}$ = número de cães por grupo. Valor de referência para PU/C: < 0,02 (Thrall et al., 2015). Letras diferentes nas barras representam a diferença entre os valores médios. ${ }^{b} \mathrm{P}<0,05$ versus grupo controle. Fonte: Própria autoria.

\subsubsection{Avaliação ultrassonográfica dos rins}

Todos os cães com DRC apresentaram alterações estruturais importantes nos rins, dentre os quais 78,6\% apresentaram contornos irregulares, 85,7\% apresentaram perda do limite corticomedular e ecogenicidade elevada na região cortical, 64,3\% apresentaram tamanho renal reduzido e em $35,7 \%$ dos casos foi observada a presença do sinal medular.

Imagens ultrassonográficas representativas dos rins de um cão com DRC são mostradas na Figura 9.

Figura 9 - Imagens ultrassonográficas dos rins de cão.

(A)

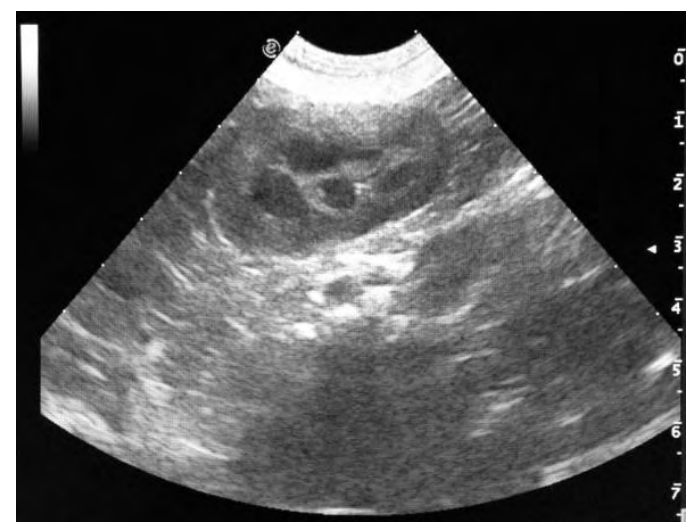

(B)

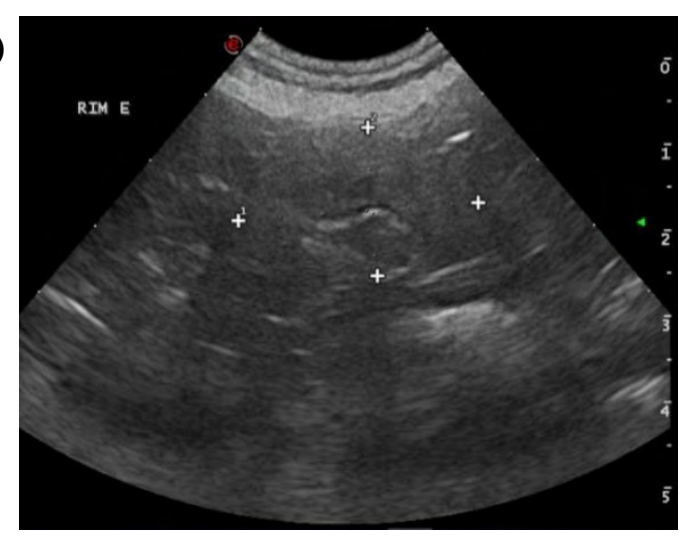

A: Rim de um cão saudável, com contornos regulares e limite corticomedular bem definido. B: Rim de um cão com doença renal crônica, com contornos irregulares, região cortical hiperecogênica e perda do limite corticomedular. Fonte: Serviço de diagnóstico por imagem da Unidade Didático Clínico Hospitalar (UDCH) da FZEA/USP. 


\subsubsection{Estadiamento da DRC}

De acordo com os resultados da avaliação inicial e as instruções da IRIS (2017), os cães foram classificados nos estádios da DRC. Estas informações constam da Tabela 7.

Tabela 7 - Estadiamento da doença renal crônica (DRC) dos cães incluídos neste estudo.

\begin{tabular}{c|cc}
\hline Cão & & Estadiamento da DRC \\
\hline $\mathbf{1}$ & 1 & normotenso-proteinúrico \\
$\mathbf{2}$ & 1 & normotenso-proteinúrico \\
$\mathbf{3}$ & 3 & normotenso-proteinúrico \\
$\mathbf{4}$ & 2 & normotenso-proteinúrico \\
$\mathbf{5}$ & 2 & normotenso-proteinúrico \\
$\mathbf{6}$ & 4 & pré-hipertenso-proteinúrico \\
$\mathbf{7}$ & 1 & normotenso-proteinúrico \\
$\mathbf{8}$ & 3 & hipertenso grave-proteinúrico \\
$\mathbf{9}$ & 3 & normotenso-proteinúrico \\
$\mathbf{1 0}$ & 3 & normotenso-proteinúrico \\
$\mathbf{1 1}$ & 4 & normotenso-proteinúrico \\
$\mathbf{1 2}$ & 3 & normotenso-proteinúrico \\
$\mathbf{1 3}$ & 3 & normotenso-proteinúrico \\
$\mathbf{1 4}$ & 4 & pré-hipertenso-proteinúrico \\
\hline
\end{tabular}

Fonte: Própria autoria.

\subsection{AVALIAÇÃO DO RNA EXTRAIIDO DO SEDIMENTO URINÁRIO DOS CÃES}

Os valores individuais e médios da concentração do RNA urinário e as razões 260/230 e 260/280 são apresentados na Tabela 8. Não foram observadas diferenças entre os grupos em relação a estes parâmetros do RNA.

As concentrações do RNA urinário foram satisfatórias, assim como a respectivas razões de pureza (260/280 e 260/230) nos grupos controle e DRC. Para este estudo, foram utilizadas somente as amostras de RNA que apresentaram integridade das bandas ribossomais 28 s e 18 s, após a eletroforese em gel de agarose $2 \%$ (Figura 10). 
Tabela 8 - Valores individuais e médios da concentração do RNA urinário e sua respectiva razão de pureza dos cães do grupo controle e DRC

\begin{tabular}{c|ccc|ccc}
\hline & \multicolumn{3}{|c|}{ Controle (n=10) } & \multicolumn{3}{c}{ DRC (n=14) } \\
\cline { 2 - 7 } Cães & $\begin{array}{c}\text { Concentração } \\
\text { (ng/uL) }\end{array}$ & $\mathbf{2 6 0 / 2 8 0}$ & $\mathbf{2 6 0 / 2 3 0}$ & $\begin{array}{c}\text { Concentração } \\
\text { (ng/uL) }\end{array}$ & $\mathbf{2 6 0 / 2 8 0}$ & $\mathbf{2 6 0 / 2 3 0}$ \\
\hline $\mathbf{1}$ & 45,53 & 1,40 & 0,50 & 58,59 & 1,38 & 0,21 \\
$\mathbf{2}$ & 15,32 & 1,30 & 0,40 & 6,14 & 1,40 & 0,50 \\
$\mathbf{3}$ & 74,56 & 1,38 & 0,20 & 184,38 & 1,70 & 0,70 \\
$\mathbf{4}$ & 46,13 & 1,49 & 0,25 & 7,56 & 1,40 & 0,55 \\
$\mathbf{5}$ & 36,77 & 1,50 & 0,30 & 5,17 & 1,30 & 0,52 \\
$\mathbf{6}$ & 10,33 & 1,65 & 0,90 & 4,52 & 1,30 & 0,35 \\
$\mathbf{7}$ & 81,07 & 1,45 & 0,30 & 29,64 & 1,43 & 0,15 \\
$\mathbf{8}$ & 7,72 & 1,13 & 0,60 & 595,17 & 1,93 & 2,02 \\
$\mathbf{9}$ & 10,61 & 1,30 & 0,15 & 5,53 & 1,30 & 0,27 \\
$\mathbf{1 0}$ & 5,82 & 1,45 & 0,40 & 70,63 & 1,49 & 0,10 \\
$\mathbf{1 1}$ & --- & --- & --- & 5,20 & 1,38 & 0,16 \\
$\mathbf{1 2}$ & --- & --- & --- & 7,20 & 1,35 & 0,14 \\
$\mathbf{1 3}$ & --- & --- & --- & 6,78 & 1,60 & 0,40 \\
$\mathbf{1 4}$ & --- & --- & --- & 10,91 & 1,47 & 0,12 \\
\hline Médias & $33,40 \pm$ & $1,40 \pm$ & $0,40 \pm$ & $71,24 \pm$ & $1,46 \pm$ & $0,44 \pm$ \\
\hline
\end{tabular}

$\mathrm{DRC}=$ doença renal crônica; $\mathrm{n}=$ número de animais por grupo; $\pm=$ erro padrão.

Fonte: Própria autoria.

Figura 10 - Eletroforese do RNA total extraído do sedimento urinário de cães

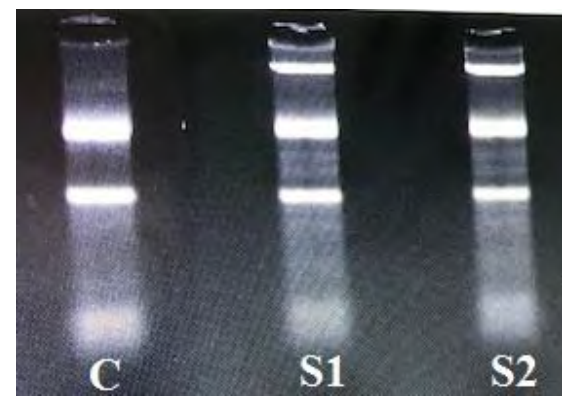

DNA genômico

$28 \mathrm{~s}$

$18 \mathrm{~s}$

$\mathrm{C}=\mathrm{RNA}$ total isolado de células de pulmão de camundongo (controle). S1 e S2 = RNA total do sedimento urinário de cães. Em evidência, as bandas do RNA ribossomal ( $28 \mathrm{~s} \mathrm{e} 18 \mathrm{~s})$ nas três amostras (C, S1 e S2) e a banda correspondente ao DNA genômico nas amostras $\mathrm{C} 1$ e C2, que não haviam sido tratadas com DNAse. Fonte: Própria autoria.

\subsection{PADRONIZAÇÃO DO PCR}

\subsubsection{Curvas de Melting}

Representações das curvas de Melting para os alvos 18s, podocina e nefrina podem ser observadas na Figura 11. Nota-se que, a partir da temperatura de $75^{\circ} \mathrm{C}$, as curvas passam a 
apresentar grandes picos e os mesmos são coincidentes para as várias amostras, indicando que ocorreu amplificação do produto de PCR desejado, neste caso, 18s, podocina e nefrina.

Figura 11 - Curvas de Melting

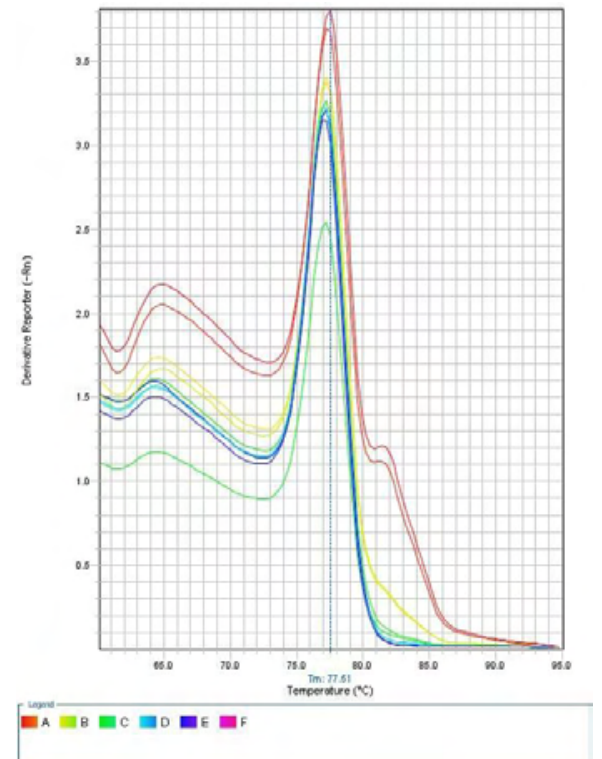

(A)

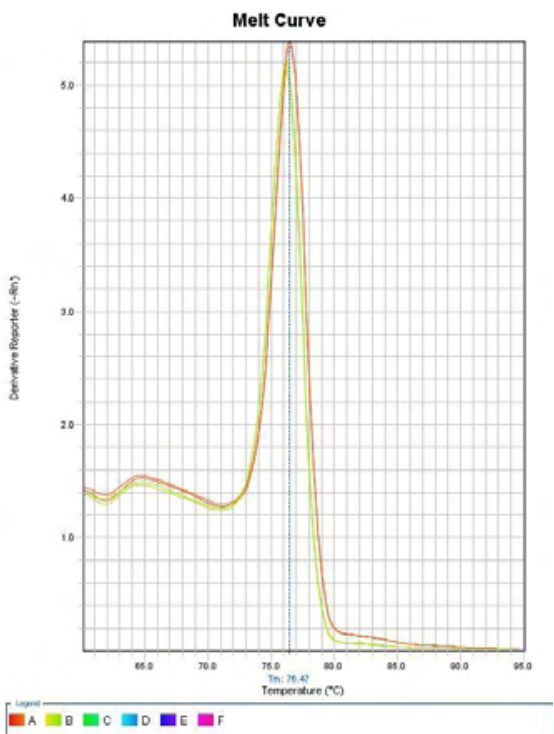

(B)

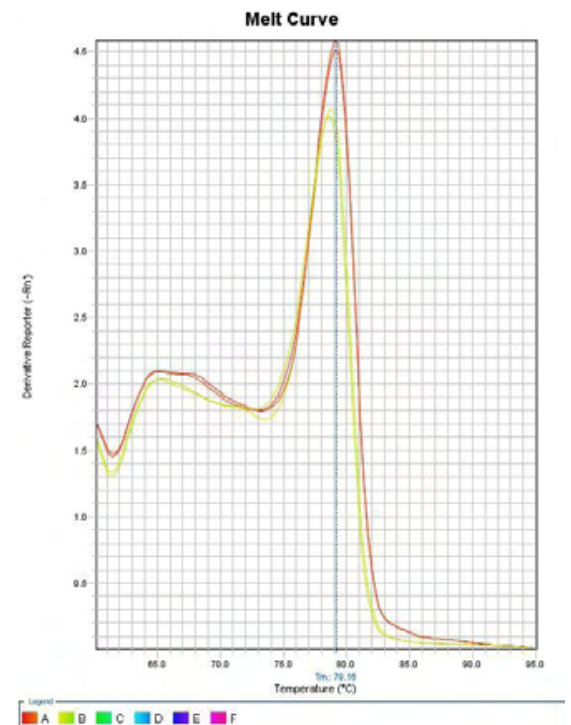

(C)

A: Curva de Melting do 18S; B: Curva de Melting da podocina; C: Curva de Melting da nefrina. Tm $=$ temperatura de Melting. $-\mathrm{Rn}=$ quantidade de fluorescência emitida pelos fragmentos dissociados. Fonte: StepOne System. 
6.4.2 Detecção do NPHS1 e NPHS2 e 18S no sedimento urinário dos cães

Entre as 10 amostras de sedimento urinário do grupo controle, o NPHS1 foi detectado em $4(40 \%)$ e entre as 5 amostras do grupo $\mathrm{DRC}_{1-2}$ e as 9 amostras do grupo $\mathrm{DRC}_{3-4}$, o NPHS1 foi detectado em $3(60 \%)$ e 1 (11\%), respectivamente, de modo que a porcentagem de detecção do NPHS1 foi maior nos cães do grupo $\mathrm{DRC}_{1-2}$ (Tabela 9) e menor no grupo $\mathrm{DRC}_{3-4}$ (Tabela 10$)$, em comparação ao grupo controle $(\mathrm{P}<0,001)$.

Tabela 9 - Porcentagem de detecção do NPHS1 nas amostras do sedimento urinário dos cães dos grupos controle e $\mathrm{DRC}_{1-2}$

\begin{tabular}{cccc}
\hline Grupos & Detectado & Não detectado & P valor \\
\hline Controle $(\mathbf{n}=\mathbf{1 0})$ & $40 \%$ & $60 \%$ & $<0,001$ \\
DRC $_{\mathbf{1 - 2}}(\mathbf{n}=\mathbf{5})$ & $\mathbf{6 0} \%$ & $40 \%$ &
\end{tabular}

$\mathrm{DRC}=$ doença renal crônica em estádios 1-2. NPHS1 = RNAm nefrina. Fonte: Própria autoria.

Tabela 10 - Porcentagem de detecção do NPHS1 nas amostras do sedimento urinário dos cães dos grupos controle e $\mathrm{DRC}_{3-4}$

\begin{tabular}{cccc}
\hline Grupos & Detectado & Não detectado & P valor \\
\hline Controle $(\mathbf{n = 1 0})$ & $40 \%$ & $60 \%$ & $<0,001$ \\
$\mathbf{D R C}_{\mathbf{3 - 4}}(\mathbf{n}=\mathbf{9})$ & $\mathbf{1 1 \%}$ & $89 \%$ &
\end{tabular}

$\mathrm{DRC}=$ doença renal crônica em estádios 3-4. NPHS1 = RNAm nefrina. Fonte: Própria autoria.

Entre as 10 amostras de sedimento urinário do grupo controle, o NPHS2 foi detectado em 2 (20\%) e entre as 5 amostras do grupo $\mathrm{DRC}_{1-2}$ e as 9 amostras do grupo $\mathrm{DRC}_{3-4}$, o NPHS1 foi detectado em $4(80 \%)$ e $1(11 \%)$, respectivamente, sendo assim, a porcentagem de detecção do NPHS2 também foi maior nos cães do grupo $\mathrm{DRC}_{1-2}$ (Tabela 9) e menor no grupo $\mathrm{DRC}_{3-4}$ (Tabela 10$)$, em comparação ao grupo controle $(\mathrm{P}<0,001)$.

Tabela 11 - Porcentagem de detecção do NPHS2 nas amostras do sedimento urinário dos cães dos grupos controle e $\mathrm{DRC}_{1-2}$

\begin{tabular}{cccc}
\hline \multicolumn{1}{c}{ Grupos } & Detectado & Não detectado & P valor \\
\hline Controle $(\mathbf{n}=\mathbf{1 0})$ & $20 \%$ & $80 \%$ & $<0,001$ \\
DRC $_{\mathbf{1 - 2}}(\mathbf{n}=\mathbf{5})$ & $\mathbf{8 0} \%$ & $20 \%$ &
\end{tabular}

$\mathrm{DRC}=$ doença renal crônica em estádios 1-2. NPHS2 = RNAm podocina. Fonte: Própria autoria. 
Tabela 12 - Porcentagem de detecção do NPHS2 nas amostras do sedimento urinário dos cães dos grupos controle e $\mathrm{DRC}_{3-4}$

\begin{tabular}{cccc}
\hline \multicolumn{1}{c}{ Grupos } & Detectado & Não detectado & P valor \\
\hline Controle $(\mathbf{n}=\mathbf{1 0})$ & $20 \%$ & $80 \%$ & $<0,001$ \\
$\mathbf{D R C}_{\mathbf{3 - 4}}(\mathbf{n}=\mathbf{9})$ & $\mathbf{1 1} \%$ & $89 \%$ &
\end{tabular}

$\mathrm{DRC}=$ doença renal crônica em estádios 3-4. NPHS2 = RNAm podocina. Fonte: Própria autoria.

O 18S foi detectado em todas as amostras de sedimento urinário dos cães.

6.4.3 Comparação entre os grupos em relação à expressão relativa do NPHS1 e NPHS2 no sedimento urinário

Não foram observadas diferenças entre os grupos em relação à expressão do NPHS1 no sedimento urinário $(\mathrm{P}=0,511)$. $\mathrm{O}$ grupo $\mathrm{DRC}_{3-4}$ apresentou menor expressão para $\mathrm{o}$ NPHS2, em comparação ao grupo $\mathrm{DRC}_{1-2}(\mathrm{P}=0,045)$, mas não diferiu do grupo controle $(\mathrm{P}=$ 0,082) (Tabela 13). Numericamente, o grupo $\mathrm{DRC}_{1-2}$ apresentou maiores valores para a expressão do RNAm para NPHS1 e NPHS2, em relação aos grupos controle e $\mathrm{DRC}_{3-4}$.

Tabela 13 - Valores médios da expressão relativa do NPHS1 e NPHS2 no sedimento urinário dos grupos experimentais

\begin{tabular}{cccc}
\hline & $\begin{array}{c}\text { Controle } \\
(\mathbf{n}=\mathbf{1 0})\end{array}$ & $\begin{array}{c}\mathbf{D R C}_{\mathbf{1 - 2}} \\
(\mathbf{n}=\mathbf{5})\end{array}$ & $\begin{array}{c}\mathbf{D R C}_{\mathbf{3 - 4}} \\
(\mathbf{n}=\mathbf{9})\end{array}$ \\
\hline NPHS1 & $-0,49 \pm 0,68 \mathrm{a}$ & $1,13 \pm 1,51 \mathrm{a}$ & $-1,17 \pm 1,07$ \\
NPHS2 & $-0,42 \pm 0,32 \mathrm{a}$ & $1,84 \pm 0,90 \mathrm{a}$ & $\mathbf{- 0 , 3 5} \pm \mathbf{0 , 6 3 c}$
\end{tabular}

$\mathrm{DRC}=$ doença renal crônica em estádios 1-2 ou 3-4. NPHS1 $=$ RNAm nefrina. $N P H S 2=$ RNAm podocina. Médias apresentadas em $\log 10 . \pm=$ erro padrão. Letras diferentes na mesma linha representam a diferença entre os valores médios. ${ }^{c} \mathrm{P}<0,05$ versus grupo $\mathrm{DRC}_{1-2}$ e $\mathrm{DRC}_{3-4}$. Fonte: Própria autoria.

\subsection{CORRELAÇÕES}

A Tabela 14 mostra as correlações entre os parâmetros avaliados, sendo que as correlações significativas $(\mathrm{P}<0,05)$ foram destacadas em negrito.

Observou-se uma correlação significativa e negativa entre a expressão relativa do NPHS1 e as concentrações séricas de ureia, creatinina, fósforo e albumina e uma correlação significativa e positiva entre o NPHS1 e o valor da densidade urinária. 
Tabela 14 - Correlações avaliadas

\begin{tabular}{lcc}
\hline & \multicolumn{2}{c}{ Expressão relativa } \\
& NPHS1 & NPHS2 \\
\hline Pressão arterial sistólica & -0.41 & -0.29 \\
Hemácias & 0.34 & 0.05 \\
Hemoglobina & 0.40 & 0.11 \\
Hematócrito & 0.37 & 0.11 \\
Leucócitos & -0.25 & -0.36 \\
Ureia & $\mathbf{- 0 . 5 4 *}$ & -0.24 \\
Creatinina & $\mathbf{- 0 . 5 2 *}$ & -0.25 \\
Sódio & -0.06 & 0.07 \\
Potássio & 0.07 & -0.04 \\
Cálcio total & -0.36 & 0.11 \\
Cálcio ionizado & -0.06 & -0.09 \\
Fósforo & $\mathbf{- 0 . 5 0 *}$ & -0.20 \\
Proteina total sérica & -0.17 & -0.16 \\
Albumina & $\mathbf{- 0 . 5 2 *}$ & 0.12 \\
PU/C & -0.17 & -0.24 \\
Densidade urinária & $\mathbf{0 . 6 0 *}$ & 0.00 \\
\hline
\end{tabular}

VCM = volume corpuscular médio; $\mathrm{HCM}=$ hemoglobina corpuscular média; $\mathrm{CHCM}$ = concentração hemoglobina corpuscular média; $\mathrm{PU} / \mathrm{C}=$ relação proteína/creatinina urinária. $* \mathrm{P}<0,05$. 


\section{DISCUSSÃO}

O grupo DRC foi composto, em sua maioria, por fêmeas com raça definida, ao contrário do que foi descrito no estudo conduzido por Zatelli et al. (2016), em que não houve predileção sexual e racial nos cães com DRC. A preferência dos tutores por de cães de raça e fêmeas poderia justificar esta diferença entre os estudos. Além disso, O' Neill et al. (2013) evidenciaram que algumas raças foram mais acometidas por esta doença, como Cocker Spaniel, Labrador Retriever e Yorkshire Terrier. No presente estudo, cães destas raças fizeram parte do grupo DRC. Em relação à idade dos cães, há uma concordância que a DRC é diagnosticada, principalmente, em cães adultos ou idosos.

Os cães do grupo DRC apresentaram as seguintes manifestações clínicas: poliúria, polidipsia, desidratação, perda de massa muscular, anemia normocítica normocrômica, azotemia, hiperfosfatemia, hipocalcemia, baixa densidade urinária, proteinúria e alterações ultrassonográficas no parênquima renal, que são consequências diretas ou indiretas da perda de néfrons funcionais, ou seja, a principal característica da DRC (BARTGES et al., 2012). Outros autores que também avaliaram cães com DRC na rotina hospitalar relataram as mesmas alterações físicas e laboratoriais observadas no presente estudo (O' NEILL et al., 2013; ZATELLI et al., 2016; CRIVELLENTI et al., 2017).

No grupo DRC, seis cães foram classificados no estádio de pré-hipertensão e um cão com hipertensão severa, sendo que a maioria destes pertencia ao grupo $\mathrm{DRC}_{3-4}$. O grupo $\mathrm{DRC}_{3-4}$ também apresentou o maior valor médio para a PAS. Concordando com este resultado, Patitucci (2013) observou que os cães classificados nos estádios mais avançados da DRC apresentam os maiores valores da PAS. A ativação crônica do SRAA, em decorrência da DRC, é uma das principais causas da elevação da PAS, devido ao aumento da resistência periférica e maior retenção de água e sódio, promovidos pela angiotensina II e a aldosterona (GALVÃO et al., 2010; BARTGES, 2012).

A proteinúria esteve presente em todos os cães do grupo DRC. Na DRC, o aumento da concentração de proteínas na urina se deve ao comprometimento da BFG, à limitada capacidade de reabsorção pelas células do túbulo proximal e à lesão das células tubulares renais, que passam a secretar proteínas no fluido tubular (VADEN; ELLIOTT, 2016). Sabese ainda, que o aumento da concentração de proteínas na urina é tóxico para as células tubulares, uma vez que ativa vias de sinalização promotoras de atrofia e fibrose tubular, o que contribui para a progressão da doença renal (NOLIN et al., 2016). Ainda de acordo com Syme 
etal. (2006), Bartges (2012) e Rudinsky et al. (2018), tanto a proteinúria, quanto a hiperfosfatemia têm sido associadas com um pior prognóstico e a progressão mais rápida da DRC em pequenos animais.

Os valores médios da concentração de potássio foram maiores no grupo $\mathrm{DRC}_{3-4}$, em comparação ao grupo controle. A concentração de potássio neste grupo também ficou no limite superior do valor de referência (DIBARTOLA, 2015). A hipercalemia pode ser uma complicação da DRC, relacionada ao aumento da ingestão de potássio na dieta, associado à baixa excreção renal e ao uso dos inibidores do SRAA (como os inibidores da ECA e a espironolactona), que diminuem a produção ou interferem no mecanismo de ação da aldosterona, que regula a excreção de potássio (SEGEV et al., 2010). No momento que os exames foram feitos, os cães com DRC não recebiam a ração coadjuvante para o tratamento da doença renal (suplementada com potássio) e tampouco os medicamentos que atuam na inibição do SRAA; sendo assim, acredita-se que a maior concentração de potássio no grupo $\mathrm{DRC}_{3-4}$ possa ser justificada pela baixa TFG.

Os resultados do presente estudo demonstraram que houve a detecção para o NPHS1 e NPHS2 no sedimento urinário dos cães controle, ou seja, em cães com excelente estado geral e com perfil renal normal, caracterizado pela manutenção da TFG e da capacidade de concentrar urina e sem proteinúria ou alterações eletrolíticas. Portanto, acredita-se que estes resultados sejam compatíveis com a podocitúria fisiológica que é acompanhada pela regeneração e diferenciação dos podócitos na BFG (TRIMARCHI, 2017). Por outro lado, o NPHS1 e NPHS2 também foi detectado no sedimento urinário do grupo DRC, mas de maneira diferencial, quando considerado o estádio da doença. Sendo assim, também foi possível caracterizar a podocitúria relacionada à DRC, como será discutido a seguir.

A porcentagem de detecção do NPHS1 e NPHS2 no sedimento urinário de cães com DRC em estádio 1 ou 2 foi maior do que em cães controle $(\mathrm{P}<0,001)$ e a expressão relativa média do NPHS1 e NPHS2 no sedimento urinário foi numericamente maior no grupo $\mathrm{DRC}_{1-2}$ do que nos grupos controle e $\mathrm{DRC}_{3-4}$, sugerindo o aumento da podocitúria. Os cães do grupo $\mathrm{DRC}_{1-2}$ apresentavam bom estado geral, sendo a poliúria e a polidipsia as principais queixas dos tutores, além disso, os exames laboratoriais não indicaram anemia, azotemia e hipertensão; porém, a hiperfosfatemia, a baixa densidade urinária e os maiores valores de proteinúria foram as principais alterações observadas neste grupo. $\mathrm{O}$ aumento da podocitúria, em conjunto com a intensa proteinúria, são fortes indicativos da presença de uma lesão glomerular ativa nos cães do grupo $\mathrm{DRC}_{1-2}$. Corroborando estes resultados, observou-se o valor médio da proteinúria $>2$ no grupo $\mathrm{DRC}_{1-2}$, que também sugere uma proteinúria de 
origem glomerular (LEES et al., 2005; HARLEY; LANGSTON, 2012). Os cães com DRC em estádio inicial podem ou não evoluir para os estádios mais avançados da doença. Aparentemente, a evolução da DRC está associada à presença de uma lesão ativa (COWGILL et al., 2016).

Possivelmente, a DRC estava em progressão nos cães do grupo $\mathrm{DRC}_{1-2}$, devido à maior podocitúria e proteinúria e a baixa densidade urinária, decorrentes do comprometimento glomerular e tubular. De acordo com a literatura, algumas medidas como o controle da proteinúria e hiperfosfatemia deveriam ser adotadas neste momento, com o objetivo de retardar a progressão da DRC (BROWN, 2007; BARTGES, 2012).

Outro aspecto que poderia justificar a maior expressão do NPHS1 e NPHS2 no grupo DRC $_{1-2}$ refere-se a um mecanismo compensatório desencadeado pela doença. A DRC é caracterizada pela perda massa funcional, então, os néfrons remanescentes entram em um estado de hiperfiltração para manter a TFG. Esta compensação se deve à vasoconstrição da arteríola glomerular eferente, que provoca hipertensão nos capilares glomerulares, dilatação dos poros de filtração, aumento da TFG e da proteinúria (CARLSTRÖM; WILCOX; ARENDSHORST, 2015). Contudo, a hipertensão glomerular também aumenta o desprendimento dos podócitos da membrana basal e, portanto, a podocitúria (KRIZ; LEMLEY, 2015).

A porcentagem de detecção do NPHS1 e NPHS2 no sedimento urinário de cães com DRC em estádio 3 ou 4 foi menor do que em cães controle $(\mathrm{P}<0,001)$ e a expressão relativa média do NPHS2 no sedimento urinário foi menor em comparação ao grupo $\mathrm{DRC}_{1-2}(\mathrm{P}<$ 0,05). O conjunto destes resultados sugere a redução da podocitúria. Os cães do grupo $\mathrm{DRC}_{3-4}$ apresentaram anemia, uremia, hiperfosfatemia, maiores valores para PAS, baixa densidade urinária e proteinúria. $\mathrm{O}$ fato dos cães do grupo $\mathrm{DRC}_{3-4}$ apresentarem proteinúria e podocitúria inferiores ao grupo $\mathrm{DRC}_{1-2}$ pode ser uma consequência da grande redução do número de néfrons, devido ao estádio avançado da DRC. Neste caso, não há nenhuma medida de tratamento capaz de conter a progressão da doença.

Corroborando com os resultados apresentados, outros autores já relataram o aumento da excreção urinária do NPHS1 e NPHS2 em modelos animais (ratos) submetidos à lesão renal induzida pela toxina da difteria humana e relacionaram tais achados com a lesão na BFG (SATO et al., 2009; FUKUDA et al., 2012). Estes mesmos autores sugeriram que o aumento, seguido pela redução na excreção urinária do NPHS1 é um indicativo da progressão da doença renal em ratos. Um único estudo, que fez uma avaliação semelhante em cães com DRC provocada pela leishmaniose visceral, evidenciou a redução da 
expressão urinária do NPHS1 nos estágios mais avançados da doença, em comparação aos estágios iniciais (TORRES et al., 2016). No presente estudo, o NPHS1 e NPHS2 foram detectados em uma maior porcentagem de amostras do sedimento urinário de cães em estádio inicial da DRC, do que em amostras de cães em estádio mais avançado da doença e a expressão relativa média do $N P H S 2$ foi menor no grupo $\mathrm{DRC}_{3-4}$. Portanto, além de um indicativo de lesão glomerular ativa, o estudo do RNAm relacionado aos podócitos poderia servir como um indicador da progressão da DRC, mas para isso seria importante acompanhar um grupo de cães durante todo o curso da doença e não apenas em um único momento.

Observou-se ainda uma correlação negativa entre a expressão relativa do NPHS1 no sedimento urinário e as concentrações séricas de ureia, creatinina e fósforo, indicando que quanto maior a expressão urinária deste RNAm, menores as concentrações séricas de ureia, creatinina e fósforo. Este resultado pode indicar que, enquanto houver glomérulos capazes de manter a TFG, as concentrações de ureia, creatinina e fósforo não serão alteradas, mesmo com perda de podócitos. Por outro lado, a correlação negativa entre a expressão relativa do NPHS1 no sedimento urinário e a concentração sérica de albumina, sugere que a podocitúria pode contribuir para a hipoalbuminemia em cães, possivelmente, pelo aumento da proteinúria. Não encontramos relevância clínica para a correlação positiva entre a expressão relativa do NPHS1 no sedimento urinário e a densidade urinária, além de que a maior excreção de RNA pode aumentar a quantidade de solutos na urina dos cães. Não foram verificadas correlações importantes entre a expressão relativa do NPHS2 no sedimento urinário e os demais parâmetros avaliados.

A detecção e expressão do NPHS1 e NPHS2 no sedimento urinário se mostrou uma avaliação muito promissora para a caracterização da podocitúria fisiológica e também relacionada à DRC em cães. Contudo, a identificação dos podócitos na urina, por exemplo, por citometria de fluxo, aliadas à avaliação dos podócitos por biópsia renal poderiam confirmar e garantir maior embasamento aos resultados apresentados. 


\section{CONCLUSÕES}

Os resultados da detecção do NPHS1 e NPHS2 no sedimento urinário sugeriram que os cães podem apresentar podocitúria fisiológica e relacionado à DRC. Além disso, os resultados de detecção e expressão urinária do NPHS1 e NPHS2 indicaram que a podocitúria variou de acordo com os estádios da DRC, estando aumentada nos cães em estádio 1 e 2 e diminuída nos cães em estádio 3 e 4. 


\section{REFERÊNCIAS}

ACIERNO, M. J.; LABATO, M. A. Hypertension in renal disease: diagnosis and treatment. Clinical techniques in small animal practice, v. 20, n. 1, p. 23-30, 2005.

AIRES, MM. Visão morfofuncional do rim. In: AIRES, MM. Fisiologia. 4 ed. Rio de Janeiro: Guanabara-Koogan, 2012, p. 679-851.

BALDWIN, K. et al. AAHA nutritional assessment guidelines for dogs and cats. Journal of the American Animal Hospital Association, Lakewood, v. 46, n. 4, p. 285-296, 2010.

BARTGES, J. W. Chronic kidney disease in dogs and cats. Veterinary Clinics Small Animal Practice, v. 42, p. 669-692, 2012.

BORIN, S.; CRIVELENTI, L. Z; DE BRUM, A. M. Abordagem atual da insuficiência renal crônica canina. Nucleus Animalium, v. 1, n. 1, p. 143-151, 2009.

BORTOLOTTO, L.A. Hipertensão arterial e insuficiência renal crônica. Revista Brasileira de Hipertensão, v. 15, n. 3, p. 152-155, 2008.

BRAFF, J. et al. Relationship between serum symmetric dimethylarginine concentration and glomerular filtration rate in cats. Journal of veterinary internal medicine, Philadelphia, v. 28, n. 6, p. 1699-1701, 2014.

BRAGATO, N.; BORGES, N. C.; FIORAVANTI, M. C. S. B-mode and Doppler ultrasound of chronic kidney disease in dogs and cats. Veterinary research communications, v. 41, $\mathrm{n}$. 4, p. 307-315, 2017.

BROWN, S. et al. Guidelines for the identification, evaluation, and management of systemic hypertension in dogs and cats. Journal of Veterinary Internal Medicine, Philadelphia, v. 21, n. 3, p. 542-558, 2007.

CABRAL, R. R. et al. Valores da pressão arterial em cães pelos métodos oscilométrico e Doppler vascular. Arquivo Brasileiro de Medicina Veterinária e Zootecnia, Belo Horizonte, v. 62, n. 1, p. 64-71, 2010.

CARLSTRÖM, M; WILCOX, C. S.; ARENDSHORST, W. J. Renal autoregulation in health and disease. Physiological reviews, v. 95, n. 2, p. 405-511, 2015.

CHEN, S. et al. Role of NADPH oxidase-mediated reactive oxygen species in podocyte injury. Journal BioMed Research International, v. 2013, p. 1-7, 2013.

CHUANG, P. Y.; HE, J. C. Signaling in regulation of podocyte phenotypes. Nephron Physiology, v. 111, n. 2, p. 9-15, 2009.

CORTADELLAS, O. et al. Calcium and phosphorus homeostasis in dogs with spontaneous chronic kidney disease at different stages of severity. Journal of Veterinary Internal Medicine, vol. 24, p.73-79, 2010. 
COWGILL, L. D. et al. Is progressive chronic kidney disease a slow acute kidney injury?. Veterinary Clinics: Small Animal Practice, v. 46, n. 6, p. 995-1013, 2016.

CRIVELLENTI, L. Z. et al. Occult gastrointestinal bleeding is a common finding in dogs with chronic kidney disease. Veterinary Clinical Pathology, v. 0, p. 1-6, 2017.

DIBARTOLA, S.P.; WESTROPP, J. L. Glomerulopatias. In: NELSON, R., e COUTO, C. G. Medicina interna de pequenos animais. 5. ed. Rio de Janeiro: Elsevier, 2015. p. 653-660.

DOUBLIER, S. et al. Nephrin redistribution on podocytes is a potential mechanism for proteinuria in patients with primary acquired nephrotic syndrome. American Journal of Pathology, v. 158, n. 5, 2001.

FEITOSA, F. L. F. Exame Físico Geral ou de Rotina. In: FEITOSA, F. L. F. Semiologia veterinária: a arte do diagnóstico: cães, gatos, equinos, ruminantes e silvestres. 2. ed. São Paulo: Roca, 2008, p. 78-102.

FUJII, T. et al. The role of renal sympathetic nervous system in the pathogenesis of ischemic acute renal failure. European Journal of Pharmacology, Amsterdam, v. 481, p. 241-248, 2003.

FUKUDA, A. et al. Angiotensin II-dependent persistent podocyte loss from destabilized glomeruli causes progression of end stage kidney disease. Kidney international, v. 81, n. 1, p. 40-55, 2012.

GALVÃO, A. L. B. et al. Hipertensão arterial na doença renal crônica em pequenos animaisrevisão de literatura. Nucleus Animalium, v. 2, n. 1, 2010.

GEIST, M.; LANGSTON, C. Laboratory evaluation of kidney disease. Veterinary Medicine, Chicago, p. 243-251. 2011.

GOBE, G. C.; JOHNSON, D. W. Distal tubular epithelial cells of the kidney: Potential support for proximal tubular cell survival after renal injury. The International Journal of Biochemistry \& Cell Biology, Exeter, v. 39, p. 1551- 1561, 2007.

GÖDEL, M. et al. A novel domain regulating degradation of the glomerular slit diaphragm protein podocin in cell culture systems. Plos one, v. 8, n. 2, p. 1-9, 2013.

GRAUER, G.F. Measurement, interpretation, and implication of proteinúria and albuminuria. Veterinary Clinics of North America: Small Animal Practice, v.35, p. 283-295, 2007.

GRAUER, G. F. Measurement and interpretation of proteinuria and albuminuria. Disponível em: http://www.iris-kidney.com/education/proteinuria.html. Acesso em: 28 Agosto. 2017.

HALL, J. A. et al. A longitudinal study on the acceptance and effects of a therapeutic renal food in pet dogs with IRIS-Stage 1 chronic kidney disease. Journal of Animal Physiology and Animal Nutrition, p. 1-11, 2018.

HARLEY, L., LANGSTON, C. Proteinuria in dogs and cats. The Canadian veterinary journal, v. 53, n. 6, p. 631, 2012. 
HOKAMP, J.A. et al. Correlation of electrophoretic urine protein banding patterns with severity of renal damage in dogs with proteinuric chronic kidney disease. Veterinary Clinical Pathology, v. 47, n. 3, p. 425-434, 2018.

ICHII, O. et al. Pathological correlations between podocyte injuries and renal functions in canine and feline chronic kidney diseases. Histology and Histopathology, v. 26, p. 12431255, 2011.

INOUE, K.; ISHIBE, S. Podocyte endocytosis in the regulation of the glomerular filtration barrier. American Journal of Physiology-Renal Physiology, v. 309, n. 5, p. 398-405, 2015.

IRIS. International Renal Interest Society. Staging Chronic Kidney Disease (CKD). Disponível em: http://www.iris-kidney.com/pdf/3_staging-of-ckd.pdf. Acesso em: 27 Agosto. 2017.

JACOB, F. et al. Evaluation of the association between initial proteinuria and morbidity rate or death in dogs with naturally occurring chronic renal failure. Journal of the American Veterinary Medical Association, v. 226, p. 393-400, 2005.

JUNQUEIRA, L.C; CARNEIRO, J. Biologia celular e molecular. In: JUNQUEIRA, L.C; CARNEIRO, J. Anatomia Renal. 11. ed. Rio de Janeiro: Guanabara Koogan, 2012. p. 110115.

KIERSZENBAUM, A.L. Histologia e Biologia celular - Uma introdução à patologia. In: KIERSZENBAUM, A.L. Anatomia e fisiologia renal. 2. ed. Rio de Janeiro: Elsevier, 2008. p. $360-370$.

KÖNIG, H. E.; MAIERL, J.; LIEBICH, H.G. Sistema urinário. In: KÖNIG, H. E.; LIEBICH, H.G. Anatomia dos Animais Domésticos: Texto e Atlas Colorido. 6 ed. Porto Alegre: Artmed Editora, 2016, p. 399-412.

KOSTOVSKA, I. et al. Nephrin and podocalyxin - new podocyte proteins for early detection of secondary nephropathies. Bantao Journal, v. 14, n. 1, p. 11-16, 2016.

KRIZ, W.; LEMLEY, K.V. A potential role for mechanical forces in the detachment of podocytes and the progression of CKD. Journal of the American Society of Nephrology, v. 26, p. 258-269, 2015.

LAFLAMME, D. P. Development and validation of a body condition score system for dogs: a clinical tool. Canine Practice, v. 22, n. 3, p. 10-15, 1997.

LEES, G. E. et al. Assessment and management of proteinuria in dogs and cats: 2004 ACVIM Forum Consensus Statement (small animal). Journal of veterinary internal medicine, v. 19, n. 3, p. 377-385, 2005.

LIVAK, K.J.; SCHMITTGEN, T.D. Analysis of relative gene expression data using real-time quantitative PCR and the $2^{\wedge}(-\Delta \Delta C \mathrm{~T})$ method. Methods (San Diego, Calif.), v.25, n. 4, p. 402408, 2001. 
MALLIPATTU, S. K.; HE, J. C. Podocyte as a direct target for treatment of glomerular disease? American Journal of Physiology - Renal Physiology, v. 311, n. 1, p. 46-51, 2016.

MATAVELLI, L. C. A inibição da renina e a estimulação do receptor AT2 reduzem a inflamação e o estresse oxidativo renal em um modelo experimental de nefropatia diabética. 2015. 151p. Tese (Doutorado) - Faculdade de Medicina da Universidade de São Paulo, São Paulo.

MCGROTTY, Y. Diagnosis and management of chronic kidney disease in dogs and cats. Companion Animal Practice, v.30, p.502-507, 2008.

MOSQUERA, E. M. Influência de la insulin sobre el enzima convertidor de angiotensina 2 (ECA2) en la nefropatia diabética experimental. 2013. 125 p. Tese (Doutorado) Universitat Autonoma de Barcelona, Barcelona.

NABITY, M. B. et al. Proteomic analysis of urine from male dogs during early stages of tubulointersticial injury in a canine model of progressive glomerular disease. Veterinary Clinical Pathology, v. 40, p. 222-236, 2011.

NELSON, R. W; COUTO, C. G. Medicina interna de pequenos animais. In: DIBARTOLA, S. P; WESTROPP, J. L. Doenças do trato urinário. 5. ed. Rio de Janeiro: Elsevier, 2015. p. 669- 678.

NICHOLS, R. Polyuria and Polydipsia. Veterinary Clinics of North America: Small Animal Practice, v.31, p.833, 2001.

NOLIN, A. C. et al. Proteinuria causes dysfunctional autophagy in the proximal tubule. American Journal of Physiology-Renal Physiology, v. 311, n. 6, p. 1271-1279, 2016.

NOTOMI, M. K. et al. Estudo retrospectivo de casos de insuficiência renal crônica em cães no período de 1999 a 2002. Brazilian Journal of Veterinary Research and Animal Science, v. 43, p. 12-22, 2006.

O'NEILL, D. G. et al. Chronic kidney disease in dogs in UK veterinary practices: prevalence, risk factors, and survival. Journal of Veterinary Internal Medicine, v. 27. n. 4, p. 814-821, 2013.

PATITUCCI, L.T. Avaliação clínico-laboratorial e perfil eletroforético das proteínas urinárias de cães de acordo com o estadiamento da doença renal crônica. 2013. Tese (Mestrado) - Universidade Federal Fluminense, Niterói.

POLZIN, D.J.; OSBORNE, C.A.; ROSS S. Chronic renal failure. In: ETTINGER

S.J.; FELDMAN E.C. Textbook of veterinary internal medicine. 6. ed. St. Louis: Saunders, 2005. p.1756-1785.

POLZIN, D. J. 11 Guidelines for conservatively treating chronic kidney disease. Veterinary Medicine, p.788-799, 2007.

POLZIN, D. J. Chronic kidney disease in small animals. The Veterinary Clinics of North America: Small Animal Practice, v. 41, p. 15-30, 2011. 
POLZIN, D. J . Evidence-based step-wise approach to managing chronic kidney disease in dogs and cats. Journal of Veterinary Emergency and Critical Care, v. 23, p. 1-11, 2013.

QUAGGIN, S. E. Genetic susceptibility to HIV-associated nephropathy. The Journal of clinical investigation, v. 119, n. 5, p. 1085, 2009.

ROSS, E. A. Congestive renal failure: the pathophysiology and treatment of renal venous hypertension. Journal of Cardiac Failure, Washington, v. 18, n. 12, p. 930-938, 2012.

RUDINSKY, A. J. et al. Factors associated with survival in dogs with chronic kidney disease. Journal of veterinary internal medicine, v. 32, n. 6, p. 1977-1982, 2018.

RUFATO, F. H. F. et al. Insuficiência renal em cães e gatos. Revista Eletrônica do Univar, n.6, p. 167-173, 2011.

SABINO, A.R.P. et al. Detection of podocyturia in patients with lupus nephritis. Journal Brasileiro de Nefrologia, v. 35, n. 4, p. 252-258, 2013.

SATO, Y. et al. Urine Podocyte mRNAs Mark Progression of Renal Disease. Journal of the American Society of Nephrology, v. 20, p. 1041-1052, 2009.

SCHMIEDT, C. W. et al. Bilateral renal ischemia as a model of acute kidney injury in cats. Research in Veterinary Science, London, v. 93, p. 950-959, 2012.

SEGEV, G. et al. Correction of hyperkalemia in dogs with chronic kidney disease consuming commercial renal therapeutic diets by a potassium-reduced home-prepared diet. Journal of veterinary internal medicine, v. 24, n. 3, p. 546-550, 2010.

SOUZA, M. H. L.; ELIAS, D. O. Fisiologia renal. In: SOUZA, M.H.L. Fundamentos da circulação extracorpórea. 2 ed. Rio de Janeiro: Centro Editorial Alfa Rio, 2006. 101-113 p.

SYME, H. M. et al. Survival of cats with naturally occurring chronic renal failure is related to severity of proteinuria. Journal Veterinary Internal Medicine, v. 20, p. 528-35, 2006.

THRALL, M. A. et al. Hematologia e Bioquímica Clínica Veterinária. 2. ed. Roca: Brasil, 2015.

TIMM, J. R. T. et al. Effect of cholecalciferol supplementation on urine podocyte-associated messenger RNAs in patients with chronic kidney disease. Brazilian Journal of Nephrology, v. 38, n. 2, p. 173-182, 2016.

TORRES, M.M. et al. Nephrin gene expression in chronic kidney disease of dogs with Leishmania (Leishmania) infantum chagasi. The Brazilian Journal of Infectious Diseases, v. 20, n. 5, p. 516-518, 2016.

TRIMARCHI, H. Podocyturia. What is in a name? Journal of Translation Internal Medicine, v. 3, n. 2, p. 51-56, 2015.

TRIMARCHI, H. Podocyturia: potential applications and current limitations. World journal of nephrology, v. 6, n. 5, p. 221, 2017. 
VADEN, S. L.; ELLIOTT, J. Management of proteinuria in dogs and cats with chronic kidney disease. Veterinary Clinics of North America: Small Animal Practice, v. 46, p. 1115-1130, 2016.

VANHOLDER. R. et al. What is new in uremic toxicity? Pediatric Nephrology. v. 23, p. 1211-1221, 2008.

WAKI, M. R. et al. Classificação em estágios da doença renal crônica em cães e gatosabordagem clínica, laboratorial e terapêutica. Ciência Rural, v. 40, n. 10, 2010.

WICKMAN, L. et al. Urine podocyte mRNAs, proteinuria, and progression in human glomerular diseases. Journal of the American Society of Nephrology, v. 24, n. 12, p. 20812095, 2013.

YE, J. et al. Primer-BLAST: A tool to design target-specific primers for polymerase chain reaction. BMC Bioinformatics, v, 525, p. 256-260, 2015.

YERRAMILLI, M. et al. Kidney disease and the nexus of chronic kidney disease and acute kidney injury: the role of novel biomarkers as early and accurate diagnostics. Veterinary Clinics: Small Animal Practice, v. 46, n. 6, p. 961-993, 2016.

YU, D. et al. Urinary podocyte loss is a more specific marker of ongoing glomerular damage than proteinuria. Journal of the American Society of Nephrology, v. 16, p. 1733-41, 2005.

ZATELLI, A. et al. The effect of renal diet in association with enalapril or benazepril on proteinuria in dogs with proteinuric chronic kidney disease. Open Veterinary Journal, v. 6, n. 2, p. 121-127, 2016. 